\title{
FGF23 and Phosphate-Cardiovascular Toxins in CKD
}

\author{
Isabel Vogt, Dieter Haffner and Maren Leifheit-Nestler *(D) \\ Department of Pediatric Kidney, Liver and Metabolic Diseases Hannover Medical School, 30625 Hannover, \\ Germany; vogt.isabel@mh-hannover.de (I.V.); haffner.dieter@mh-hannover.de (D.H.) \\ * Correspondence: leifheit-nestler.maren@mh-hannover.de; Tel.: +49-511-532-7815
}

Received: 27 September 2019; Accepted: 1 November 2019; Published: 6 November 2019

\begin{abstract}
Elevated levels of fibroblast growth factor 23 (FGF23) and phosphate are highly associated with increased cardiovascular disease and mortality in patients suffering from chronic kidney disease (CKD). As the kidney function declines, serum phosphate levels rise and subsequently induce the secretion of the phosphaturic hormone FGF23. In early stages of CKD, FGF23 prevents the increase of serum phosphate levels and thereby attenuates phosphate-induced vascular calcification, whereas in end-stage kidney disease, FGF23 fails to maintain phosphate homeostasis. Both hyperphosphatemia and elevated FGF23 levels promote the development of hypertension, vascular calcification, and left ventricular hypertrophy by distinct mechanisms. Therefore, FGF23 and phosphate are considered promising therapeutic targets to improve the cardiovascular outcome in CKD patients. Previous therapeutic strategies are based on dietary and pharmacological reduction of serum phosphate, and consequently FGF23 levels. However, clinical trials proving the effects on the cardiovascular outcome are lacking. Recent publications provide evidence for new promising therapeutic interventions, such as magnesium supplementation and direct targeting of phosphate and FGF receptors to prevent toxicity of FGF23 and hyperphosphatemia in CKD patients.
\end{abstract}

Keywords: FGF23; phosphate; chronic kidney disease; cardiovascular disease; hypertension; vascular calcification; left ventricular hypertrophy

Key Contribution: FGF23 and phosphate act as cardiovascular toxins in CKD. Thus, underlying mechanisms have to be further clarified to develop therapeutic strategies, which improve the cardiovascular outcome in CKD patients.

\section{Introduction}

The major cause of death in chronic kidney disease (CKD) patients is cardiovascular disease [1]. Besides classical risk factors like smoking, dyslipidemia, and diabetes mellitus, uremic-related mineral and bone disorders (MBD) also contribute to the increased cardiovascular morbidity and mortality in CKD patients. A central role in pathologic cardiovascular remodeling is attributed to hyperphosphatemia and highly elevated fibroblast growth factor 23 (FGF23) levels [2-4]. Hyperphosphatemia occurs as a consequence of a decreasing glomerular filtration rate (GFR) and is known to induce vascular calcification [5]. The phosphaturic hormone FGF23 is essential for the regulation of phosphate levels in CKD patients, but excessive FGF23 levels are also associated with left ventricular hypertrophy (LVH), cardiac fibrosis, and hypertension [6-8]. These controversial aspects of FGF23 in CKD patients have to be taken into account when addressing FGF23 as a therapeutic target. In this review, we summarize the current knowledge of the role of FGF23 on the phosphate homeostasis in health and CKD, as well as their contribution to cardiovascular diseases. Moreover, we discuss therapeutic strategies to lower serum phosphate and FGF23 levels and how this affects the cardiovascular outcome of CKD patients. 


\section{FGF23 and its Functions in Phosphate Homeostasis}

The key role of the endocrine hormone FGF23 is to maintain phosphate homeostasis. FGF23 is mainly synthesized by osteocytes in the bone. Stimulators of FGF23 secretion are primarily 1,25-dihydroxy vitamin $\mathrm{D}(1,25(\mathrm{OH}) 2 \mathrm{D} 3)$, parathyroid hormone (PTH), and phosphate [9-11]. 1,25(OH)2D3 directly activates FGF23 expression by binding to the vitamin D receptor and subsequent stimulation of the FGF23 promotor region, whereas it is unknown by which mechanisms phosphate affects FGF23 expression [12,13]. Regulation of bioactive intact FGF23 levels occurs not only at the mRNA level, but also via proteolytic cleavage of the intact FGF23 into C- and N-terminal fragments by the protease Furin. Whether the cleavage fragments still have any biological activity and induce downstream signaling has to be further examined [14].

In the kidney, physiological functions of FGF23 are mediated via binding to a complex of fibroblasts growth factor receptors (FGFRs) and its specific co-receptor Klotho [15]. FGF23 lowers the renal phosphate reabsorption by activating the FGFR1-Klotho complex. Activation of the FGFR1-Klotho complex inhibits the expression and activity of the type II sodium-dependent phosphate transporters $\mathrm{NaPi}-2 \mathrm{a}$ and $\mathrm{NaPi}-2 \mathrm{c}$, and thereby promotes the renal phosphate excretion. Furthermore, FGF23 reduces 1,25(OH)2D3 serum levels by downregulating the renal expression of CYP27B1 encoding the $1 \alpha$-hydroxylase, which inhibits the conversion of the pro-hormone 25-hydroxyvitamin D3 into its active form, and by upregulating CYP24A1, which encodes the catabolic 24-hydroxylase [16]. Decreasing renal 1,25(OH)2D3 production leads to a low abundance of sodium-dependent phosphate transporter $\mathrm{NaPi}-2 \mathrm{~b}$ in the gastrointestinal tract, thereby limiting the phosphate uptake [17]. In the parathyroid gland, binding of FGF23 to the FGFR1-Klotho complex promotes the expression of the transcription factor early growth response protein 1 (EGR1) via ERK signaling. EGR1 inhibits the gene expression and secretion of PTH, which impairs the PTH-mediated resorption of phosphate from the bone [18].

\section{The Role of FGF23 and Phosphate Balance in CKD Progression}

\subsection{Early Stages of $C K D$}

In CKD patients, the mineral and bone homeostasis is disturbed owing to the gradually declining kidney function. As the glomerular filtration rate (GFR) decreases, the phosphate excretion is progressively impaired. Nevertheless, in early CKD stages, serum phosphate levels are not increased, which could be explained by higher FGF23 expression in osteocytes [19]. Recently, it was shown that high dietary phosphate uptake promotes the progression of CKD. A higher dietary phosphate load increases phosphaturia, which directly correlates with a faster decrease in GFR. The accelerated decline in GFR is possibly mediated through renal tubular injury [20]. There is also evidence that dietary phosphate uptake regulates serum FGF23 levels in the healthy population and CKD patients with moderately decreased kidney function, but the exact signaling mechanism of how phosphate stimulates FGF23 secretion is still unclear [21,22].

In early CKD stages, elevated circulating levels of FGF23 are necessary to counteract phosphate retention and maintain normal serum phosphate levels by reducing the renal phosphate reabsorption [23]. In addition, increased FGF23 lower 1,25(OH)2D3 synthesis, which promotes hypocalcemia and subsequent secondary hyperparathyroidism (sHPT) during the further course of CKD progression [24,25]. Two animal studies highlighted the importance of FGF23-regulated phosphate homeostasis in CKD. The antibody-based neutralization of FGF23 in 5/6 nephrectomized rats, a well-established experimental CKD model, increases 1,25(OH)2D3 and reduces the sHPT, but also increases serum phosphate, and thereby aortic calcification. Owing to the massive calcification, neutralization of FGF23 leads to a higher risk of mortality in this study [7]. In the second study, CKD was induced in a conditional osteoblast/osteocyte-specific FGF 23 knockout mouse by feeding it an adenine-containing diet. Compared with wild type mice, the conditional FGF23 knockout in the bone shows higher serum phosphate levels and develops a more severe renal disease and cardiac hypertrophy [8]. These studies 
indicate that elevated FGF23 acts protectively by preventing the development of hyperphosphatemia and calcification.

\subsection{End-Stage Kidney Disease}

In end-stage kidney disease (ESKD), the phosphaturic actions of FGF23 can no longer maintain normal serum phosphate levels. Phosphate overload and FGF23-induced 1,25(OH)2D3 deficiency contribute to the downregulation of renal Klotho expression [26]. The renal Klotho deficiency reduces the affinity of FGF23 to FGFR1. This results in the development of renal FGF23 resistance, and thus an inhibition of the FGF23-mediated reduction of phosphate reabsorption [27]. Advanced loss of the kidney function together with the renal Klotho deficiency reduce the renal phosphate excretion [3,28]. Consequently, hyperphosphatemia manifests, although FGF23 levels increase up to 100-1000-fold in patients on hemodialysis [29-31]. The further increase of FGF23 is not only stimulated by high serum phosphate levels, but is also a result of elevated PTH levels and the frequently used 1,25(OH)2D3 therapy [32-35]. Physiologically rising FGF23 levels inhibit PTH expression and secretion, whereas in ESKD patients, the downregulation of the FGFR1-Klotho complex in the parathyroid glands causes a resistance to FGF23 [36-38]. Consequently, ESKD patients commonly exhibit hyperphosphatemia, FGF23 excess, 1,25(OH)2D3 deficiency, and sHPT.

\section{The Role of FGF23 and Phosphate in CKD-Associated Cardiovascular Diseases}

High levels of serum FGF23 and phosphate are independently associated with an increase in all-cause and cardiovascular mortality in CKD patients [29-31,39-43]. Both contribute to the development of cardiovascular disease by distinct mechanisms. Therefore, FGF23 and phosphate are considered as therapeutic targets to improve CKD-associated cardiovascular morbidity. As discussed earlier, targeting FGF23 alone deteriorates the cardiovascular outcome owing to the detrimental effects of hyperphosphatemia. Thus, a detailed understanding of the molecular insights of FGF23 and hyperphosphatemia in the development of cardiovascular disease is essential to develop successful therapeutic strategies.

\subsection{Hypertension}

The prevalence of hypertension increases with decreasing GFR in CKD patients [44]. This is at least partly because of high FGF23 and phosphate levels, as several clinical studies showed an association between increased serum FGF23 or phosphate and the presence of hypertension in CKD patients, as well as in non-CKD populations [45-49]. The ARIC (Atherosclerosis Risk in Communities) study evaluated the correlation of serum intact FGF23 levels and the development of hypertension in a large cohort of 7948 middle-aged (45-64 years) participants without previous hypertension during a median follow-up of 5.9 years. Overall, $27 \%$ of the participants developed a hypertension, whereby the prevalence increased independently of kidney function in the highest decile of serum FGF23 [45]. In the CARDIA (Coronary Artery Risk Development in Young Adults) study, the association of C-terminal FGF23 (cFGF) levels with hypertension was analyzed in a younger (18-30 years), more multiethnic population. The C-terminal FGF23 ELISA measures the total FGF23 protein including cleaved and full length FGF23 isoforms. In total, $35.2 \%$ of 1758 participants without pre-existing hypertensive or other cardiovascular diseases developed hypertension during a ten-year period from year 20 to 30 . The risk of developing hypertension was $45 \%$ greater in the highest quartile of cFGF23 levels compared with the lowest quartile [46]. These clinical studies provide evidence that FGF23 might be a causal factor in the development of hypertension in CKD patients.

Therefore, FGF23 is thought to contribute to the development of hypertension by modulating the renin-angiotensin-aldosterone system (RAAS) (Figure 1). Experimental studies indicate that FGF23-mediated 1,25(OH)2D3 deficiency activates the RAAS. Disruption of 1,25(OH)2D3 signaling in vitamin $\mathrm{D}$ receptor null mice promotes renal renin expression and subsequent production of the vasoconstrictor angiotensin II (AngII). Ultimately, this leads to the development of hypertension [50,51]. 
FGF23 might activate the RAAS also by directly suppressing the angiotensin-converting enzyme 2 (ACE2). ACE2 catalyzes the conversion of AngII into the vasodilative angiotensin I (AngI); thus, suppression of ACE2 via FGF23 also results in increased AngII levels [52,53]. Another experimental study suggests that FGF23 controls renal sodium reabsorption by regulating the abundance of $\mathrm{Na}^{+} \mathrm{Cl}^{-}$ co-transporter (NCC) in the distal tubule (Figure 1). Through stimulation of NCC expression, FGF23 increases renal $\mathrm{Na}^{+}$retention, which consequently triggers plasma volume expansion and, consequently, hypertension [54].

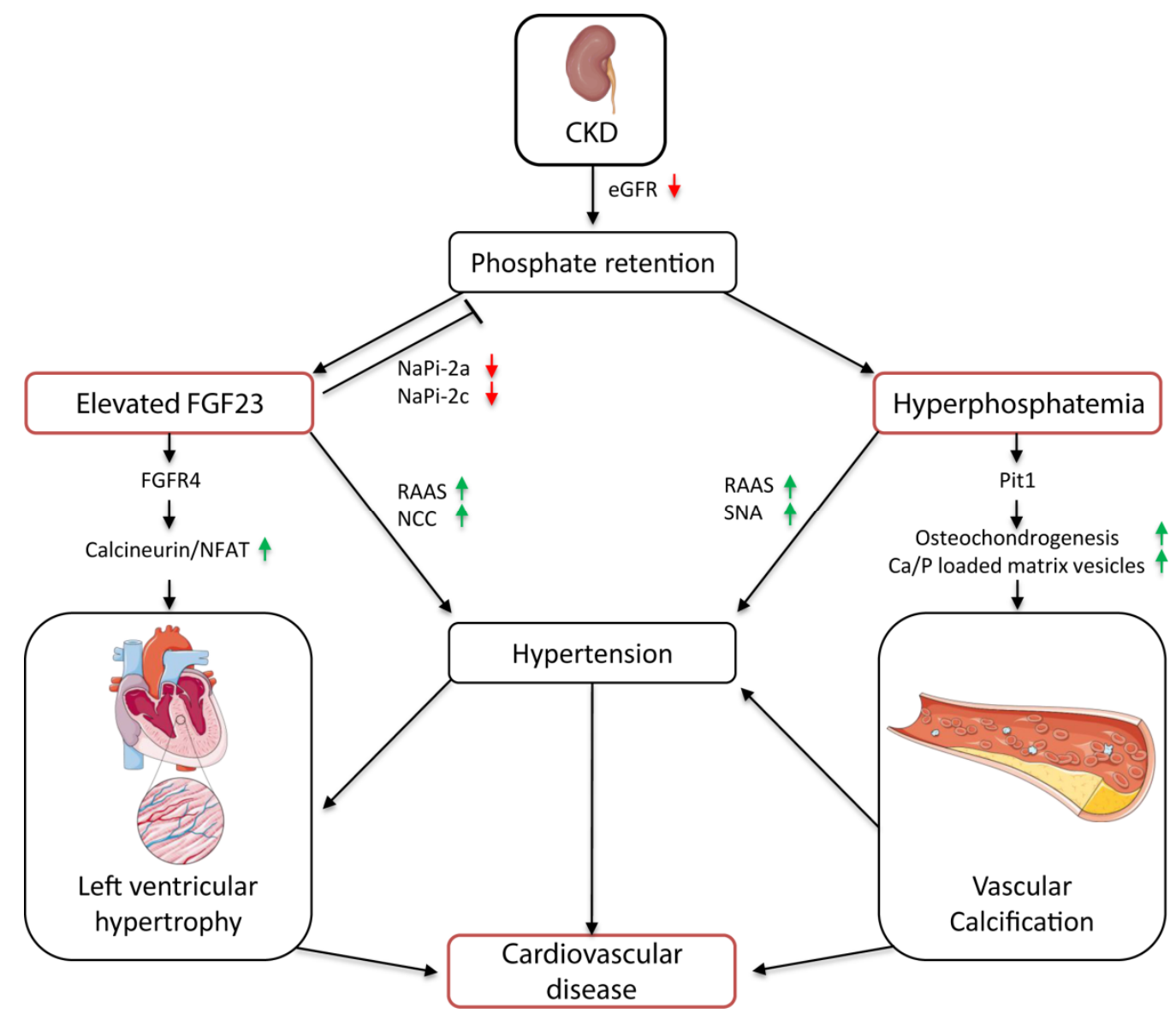

Figure 1. Cardiovascular pathomechanisms of elevated FGF23 and hyperphosphatemia in chronic kidney disease (CKD). The phosphate excretion attenuates with declining kidney function. Resulting FGF23 elevation counteracts the phosphate retention by downregulating NaPi-2a/c in the kidney, but also directly promotes LVH via FGFR4-calcineruin-NFAT signaling. FGF23 induces hypertension by activation of the RAAS and NCC expression. Hyperphosphatemia stimulates the osteochondrogenic differentiation and release of $\mathrm{Ca} / \mathrm{P}$ loaded vesicles in VSMCs via Pit-1, and thereby induces VC. Phosphate-induced vascular calcification (VC) together with activation of the RAAS and SNA contribute to the development of hypertension. eGFR, estimated glomerulus filtration rate; $\mathrm{NaPi}-2 \mathrm{a} / \mathrm{c}$, type IIa/c sodium-dependent phosphate transporter; FGFR4, fibroblast growth factor receptor 4; NFAT, nuclear factor of activated T-cells; RAAS, renin-angiotensin-aldosterone system; $\mathrm{NCC}, \mathrm{Na}^{+} \mathrm{Cl}^{-}$co-transporter; SNA, sympathetic nerve system; VC, vascular calcification.

Besides FGF23, a large prospective study with more than 9000 hypertensive participants showed that serum phosphate levels at the initial presentation are associated with increased systolic blood pressure (BP) at five years of follow up. However, this study did not allow any conclusions on whether serum phosphate levels directly correlate with hypertension, because only baseline phosphate levels were measured in the beginning of the study [55]. In a small study of 30 diabetic CKD and 23 non-diabetic CKD patients, serum phosphate levels correlated with increased systolic and diastolic 
$\mathrm{BP}$ in diabetic $\mathrm{CKD}$, but not in non-diabetic CKD patients [48]. Recently, a prospective randomized study investigated the effects of controlled inorganic phosphate $\left(\mathrm{P}_{\mathrm{i}}\right)$ uptake on BP in 20 healthy young adults. Controlled high dietary phosphate uptake was associated with increased systolic and diastolic BP [49]. Both studies analyzing the direct relationship between serum phosphate and hypertension were limited owing to small cohort sizes, so further clinical studies are necessary to confirm these results.

Animal studies in normotensive and spontaneously hypertensive rats revealed that a high phosphate diet triggers hypertension [56-58]. Feeding a high phosphate diet was shown to increase renin expression via PTH in healthy rats, which in turn stimulated AngII, and thereby induced hypertension [56]. Moreover, activation of the sympathetic nerve system (SNA) might be involved in phosphate-related BP elevation (Figure 1). Besides other molecular mechanisms, BP is controlled by the exercise pressor reflex, which originates in exercising muscles and is modulated by metabolic and mechanical stimuli. In previous human studies, an overactive exercise pressor reflex promotes SNA activity and increased BP in hypertensive patients $[59,60]$. In healthy rats, feeding of a high phosphate diet induced the exercise pressor reflex function together with the renal SNA activity and BP [58]. Underlying mechanisms of how phosphate alters the exercise pressor reflex are not clarified yet.

Altogether, the clinical and experimental data emphasize that high phosphate and FGF23 levels may contribute to hypertension not only in CKD patients, but also in the general population. This shows the importance of controlled dietary phosphate intake and underlines that FGF23 and phosphate represent promising therapeutic targets in treating hypertension in CKD patients.

\subsection{Vascular Calcification}

Vascular calcification (VC) describes pathological depositions of calcium-phosphate salts on the walls of blood vessels. Owing to the disturbed mineral metabolism, VC is highly prevalent and strongly associated with an increased risk of mortality in CKD patients [61-63]. The involvement of elevated FGF23 in the progress of VC is controversially discussed [64-70]. Clinical studies of 65 hemodialysis and 142 patients with CKD stages 2-5 indicate a correlation of higher FGF23 levels and increased aortic calcification $[64,65]$. In contrast, Scialla et al. reported that a much larger cohort of 1501 patients with a mean eGFR of $47 \mathrm{~mL} / \mathrm{min} / 1.73 \mathrm{~m}^{2}$ from the CRIC (Chronic Renal Insufficiency Cohort) study did not display an association between FGF23 levels and the prevalence of coronary artery calcification [66].

The CRIC study was further supported by in vitro experiments. Stimulation with FGF23 did not augment phosphate-induced calcification, neither in human vascular smooth muscles cells (VSMCs) in dependence on the $P_{\mathrm{i}}$ concentration, nor in aortic rings in the presence of soluble Klotho [66]. Equally, Lindberg et al. demonstrated that FGF23 treatment had no impact on phosphate-induced VC in bovine VSMCs [67]. Other experimental studies even attribute a protective role to FGF23 regarding the progress of VC $[7,8,68,69,71]$. As stated by Lim et al., FGF23 diminishes calcification of human VSMCs in the presence of Klotho [68]. Recently, Chen et al. further showed that overexpression of FGF23 and Klotho in rat VSMCs attenuated phosphate-induced calcification via inhibiting $W n t 7 b / \beta$-catenin signaling [71]. On the contrary, Jimbo et al. reported an enhanced phosphate-induced calcification in Klotho-overexpressing VSMCs by FGF23 [70]. A protective role of FGF23 was also demonstrated by Shalhoub et al. and White et al. as depletion of FGF23 levels in rodent CKD models leads to a more severe VC [7,8]. As CKD is a state of Klotho deficiency, there is no experimental evidence that FGF23 contributes to the progress of VC; it rather acts protectively. However, further studies are required to determine the interplay of FGF23 and Klotho levels on VC to figure out whether modulation of the FGF23-Klotho axis and downstream signaling pathways might serve as therapeutic targets in CKD patients.

In contrast to the controversially discussed role of FGF23 in the development of VC, hyperphosphatemia is strongly associated with VC (Figure 1) [72-75]. Even slightly elevated serum phosphate concentrations correlated with enhanced vascular and valvular calcification in a multiethnic study in 439 patients with moderate CKD without previous clinical cardiovascular disease [73]. 
Moreover, a study in 286 ESKD patients undergoing chronic dialysis treatment showed reinforced aortic arch calcification, which was highly associated with the degree of hyperphosphatemia [72]. In an ex vivo model of human vessel culture, long time exposure to phosphate resulted in increased calcification and vesicle deposition in vessels from stage 5 CKD patients compared with age-matched controls [76]. These findings are further supported by rodent studies, in which feeding of a $0.9 \%$ high phosphate diet compared with a $0.5 \%$ normal diet induced VC in nephrectomized mice $[74,75]$.

In vitro studies in VSMCs give evidence for mechanisms underlying the phosphate-induced VC. Phosphate uptake in VSMCs occurs via type III sodium-dependent $P_{i}$ cotransporters PiT-1 and PiT-2 [77]. Both PiT transporters exert opposing functions on VC under high phosphate conditions. PiT-1 acts pathologically by stimulating osteochondrogenic differentiation of VSMCs and release of calcium-phosphate containing vesicles, whereas PiT-2 protects against VC in VSMCs [78-81]. Elevated phosphate levels stimulate the osteochondrogenic differentiation by activating the expression of osteochondrogenic genes such as runt-related transcription factor 2 (Runx2), osteopontin (OPG), alkaline phosphatase (ALP) via bone morphogenic protein-2 (BMP-2), and Wnt/ $\beta$-catenin signaling. Furthermore, phosphate-induced downregulation of the smooth muscle (SM)-specific genes SM $\alpha$ actin and SM22 $\alpha$ contribute to the osteochondrogenic differentiation [82-87]. Recently, it was shown that the knockout of PiT-2 augmented aortic vascular calcification in uremic mice on a $1.5 \%$ high phosphate diet compared with a $0.5 \%$ normal phosphate diet. Additionally, PiT-2 deficient VSMCs showed enhanced matrix calcification, which might be mediated via downregulation of the osteoclastogenesis inhibitory factor osteoprotegerin [80]. Further in vivo and in vitro studies suggest that hyperphosphatemia contributes to VC via downregulation of the peroxisome proliferator-activated receptor (PPAR) $\gamma$. Treatment of VSMCs with phosphate as well as hyperphosphatemia in a CKD mouse model showed a downregulation in the expression of PPAR $\gamma$ and its downstream target Klotho. PPAR $\gamma$ agonists enhanced the expression of Klotho and inhibited VC [88,89]. Thus, to the authors' current knowledge, the direct induction of VC results from hyperphosphatemia rather than elevated FGF23 levels in CKD patients.

\subsection{Inflammation-Mediated Vascular Calcification}

Chronic inflammation is a risk factor for increased morbidity and mortality and contributes to the development of VC in CKD $[90,91]$. Clinical studies showed that elevated FGF23 levels are associated with higher levels of pro-inflammatory cytokines in CKD and non-CKD populations [92-94].

Experimental studies demonstrated that pro-inflammatory cytokines such as interleukin (IL)-1 $\beta$, IL-6, and tumor necrosis factor- $\alpha$ (TNF- $\alpha$ ) directly stimulate the synthesis of FGF23, and vice versa, FGF23 directly enhances the production of pro-inflammatory cytokines. This establishment of a vicious cycle augments systemic inflammation and contributes to the progression of CKD [95-99]. FGF23 promotes the expression of TNF- $\alpha$ in the kidney and via ERK signaling in macrophages $[53,98]$. Possibly, the activation of TNF- $\alpha$ production is mediated via the FGFR1-Klotho complex, which is expressed in macrophages and the kidney. Furthermore, Singh et al. showed that FGF23 stimulates the production of IL-6 and C-reactive protein (CRP) via FGFR4-mediated activation of the calcineurin-NFAT pathway in hepatocytes of 5/6 nephrectomized rats [99]. Besides FGF23, phosphate, incorporated in secondary calciprotein particles, also directly enhances the production of TNF- $\alpha$ and IL-1 $\beta$, and thereby contributes to VC $[100,101]$.

Elevated levels of the pro-inflammatory cytokines TNF- $\alpha$, IL-6, and IL- $1 \beta$ directly induce VC in VSMCs by stimulating their osteochondrogenic differentiation [100,102-104]. TNF- $\alpha$ activates nuclear factor- $\mathrm{KB}(\mathrm{NF}-\mathrm{kB})$ signaling, which induces the expression of the osteogenic transcription factor MSX-2, and subsequently the activity of the tissue non-specific alkaline phosphatase (TNAP) $[91,100,105]$. Activation of TNAP contributes to the formation of hydroxyapatite crystals [106]. Furthermore, TNF- $\alpha$ stimulates the synthesis of IL 6, which is also known to promote the osteochondrogenic differentiation of VSMCs via BMP-2-mediated upregulation of TNAP [91,107]. Besides the direct effects, inflammatory cytokines also contribute indirectly to VC in CKD by inducing the production of reactive oxygen 
species (ROS) and reducing fetuin-A levels, which is an important inhibitor of calcification $[108,109]$. As described earlier, the direct induction of VC primarily results from hyperphosphatemia, whereas the inflammation-mediated VC is promoted by elevated FGF23 and phosphate levels.

\subsection{Left Ventricular Hypertrophy}

The prevalence of $\mathrm{LVH}$ is about $40 \%$ in patients with early stages of CKD and rises up to $75-80 \%$ in ESKD patients [110-112]. Elevated serum FGF23 levels correlate with the development of LVH not only in CKD patients, but also in the elderly population with preserved kidney function [113-116]. Likewise, LVH represents the most abundant cardiovascular disease in children with CKD. In children aged 1-21 years, the prevalence of $\mathrm{LVH}$ is lower, with 15-67\% compared with adult CKD patients, but is also associated with elevated FGF23 levels [117-119].

In vitro and in vivo studies showed that FGF23 directly causes cardiac remodeling independent of BP [120-122]. Intramyocardial or intravenous injection of FGF23 in wild type mice triggered the development of LVH. In rat cardiomyocytes, FGF23 promotes hypertrophy via FGFR4-dependent activation of the calcineurin-nuclear factor of the activated T-cells (calcineurin-NFAT) pathway, which is known to regulate hypertrophic cardiac remodeling (Figure 1) [123]. Thereby, FGF23 binds to FGFR4 independently of its co-receptor Klotho, as it is not expressed in the heart [120]. Activation of this pathway was also found in a small retrospective case-control study with childhood-onset ESKD patients. In these patients, the presence of LVH strongly correlated with increased cardiac expression of FGF23 and Klotho deficiency. Furthermore, enhanced cardiac FGF23 expression was associated with upregulation of FGFR4 and stimulation of the calcineurin-NFAT pathway in the heart [119]. However, recent publications question whether elevated FGF23 per se contributes to cardiac remodeling [124-126]. In these studies, patients with osteomalacia/hypophosphatemic rickets and animal models with X-linked hypophosphatemia display high serum FGF23 levels, but no cardiac remodeling. The underlying cause might be differences in the mineral metabolism and FGF23 concentrations, together with systemic alterations such as hypertension and inflammation. In contrast to CKD, X-linked hypophosphatemia is associated with low serum phosphate levels and FGF23 elevation and Klotho deficiency are less pronounced than in CKD patients [124-127]. There is strong evidence that FGF23 directly contributes to the development of $\mathrm{LVH}$, especially under uremic conditions, as in CKD. Indeed, further studies are necessary to determine whether FGF23 induces hypertrophy only under certain conditions.

Similar to FGF23, higher serum phosphate levels are associated with an increased left ventricular mass (LVM) and prevalence of LVH, independent of kidney function [128-132]. Baseline serum phosphate levels correlated with the development of LVH in 4005 healthy young adults of the prospective CARDIA study. Serum phosphate levels were assessed at baseline, whereas LVH was analyzed by echocardiography five years later. In total, $4.5 \%$ of participants developed LVH at five years of follow up [128]. Likewise, higher dietary phosphate uptake correlated with an increased LVM in 4494 participants without pre-existing cardiovascular disease [131]. Patients with intermediate CKD stages also exhibit an association between elevated serum phosphate levels and increased LVM [130,132]. A limitation of these clinical studies is that measurements of FGF23 levels were often not performed. Hence, the observed cardiac hypertrophy might be triggered by phosphate-induced elevations of serum FGF23 as well.

Previous animal and in vitro studies could not clarify whether phosphate directly initiates the development of LVH. Feeding of a 1.2\% high phosphate diet for eight weeks increased the LVM and promoted LVH in uremic rats, but not in sham-operated animals $[133,134]$. However, Peri-Okonny et al. did not find any changes in the left ventricular function in wild type mice fed with a $2 \%$ phosphate diet for 12 weeks [135]. In contrast, Grabner et al. and Hu et al. demonstrated that wild type mice fed with the equivalent high phosphate diet for the same time developed LVH [121,136]. The phosphate-induced cardiac hypertrophy could be prevented by a global knockout of FGFR4 [121]. This supports the hypothesis that phosphate promotes LVH by stimulating FGF23, which is known to induce cardiac hypertrophy via FGFR4. Additionally, various 1,25(OH)2D3 concentrations in a 1.6\% high phosphate 
chow influenced phosphate-mediated hypertrophy and fibrosis in the left ventricle. Low 1,25(OH)2D3 concentrations promoted fibrosis, whereas high concentrations augmented phosphate-induced cardiac hypertrophy [137]. In vitro supplementation of $P_{i}$ stimulated the expression of fibrotic proteins CTGF (connective tissue growth factor) and collagen I in neonatal rat cardiac fibroblast and CTGF in cardiomyocytes, whereas hypertrophy in cardiomyocytes was not affected [136]. In contrast, phosphate treatment induced hypertrophy in cardiomyoblasts, potentially via Erk1/2 signaling [138]. Clinical and experimental studies provide evidence that hyperphosphatemia contributes to the development of LVH. In the future, it has to be clarified whether phosphate can induce cardiac hypertrophy directly or only indirectly. Possible indirect mechanisms such as the phosphate-mediated elevation of FGF23 or development of hypertension may contribute to the development of LVH in CKD patients.

\section{Therapeutic Approaches to Inhibit FGF23- and Phosphate-Mediated Cardiovascular Disease}

According to the current knowledge, elevated FGF23 levels contribute to the development of LVH, whereas hyperphosphatemia primarily induces vascular calcification. Because serum FGF23 and phosphate levels are strongly linked to each other, therapeutic approaches should target both to improve the cardiovascular outcome in CKD patients. Thus, several phosphate-lowering therapeutic strategies are pursued, which subsequently should reduce FGF23 levels.

\subsection{Restriction of Dietary Phosphate Uptake}

One of the strategies to lower FGF23 and phosphate levels is to restrict dietary phosphate intake (Figure 2). Studies in healthy subjects showed that low dietary phosphate uptake reduced FGF23 levels, while a high uptake increased serum FGF23 $[21,139,140]$. Tsai et al. compared the effects of a very-low phosphate diet (phosphate-to-protein ratio of $8 \mathrm{mg} / \mathrm{g}$ ) and low phosphate (phosphate-to-protein ratio of $10 \mathrm{mg} / \mathrm{g}$ ) diet in hemodialysis patients. Both diets similarly reduced intact FGF23 levels, whereas phosphate levels were only lowered by the very low phosphate diet [141].

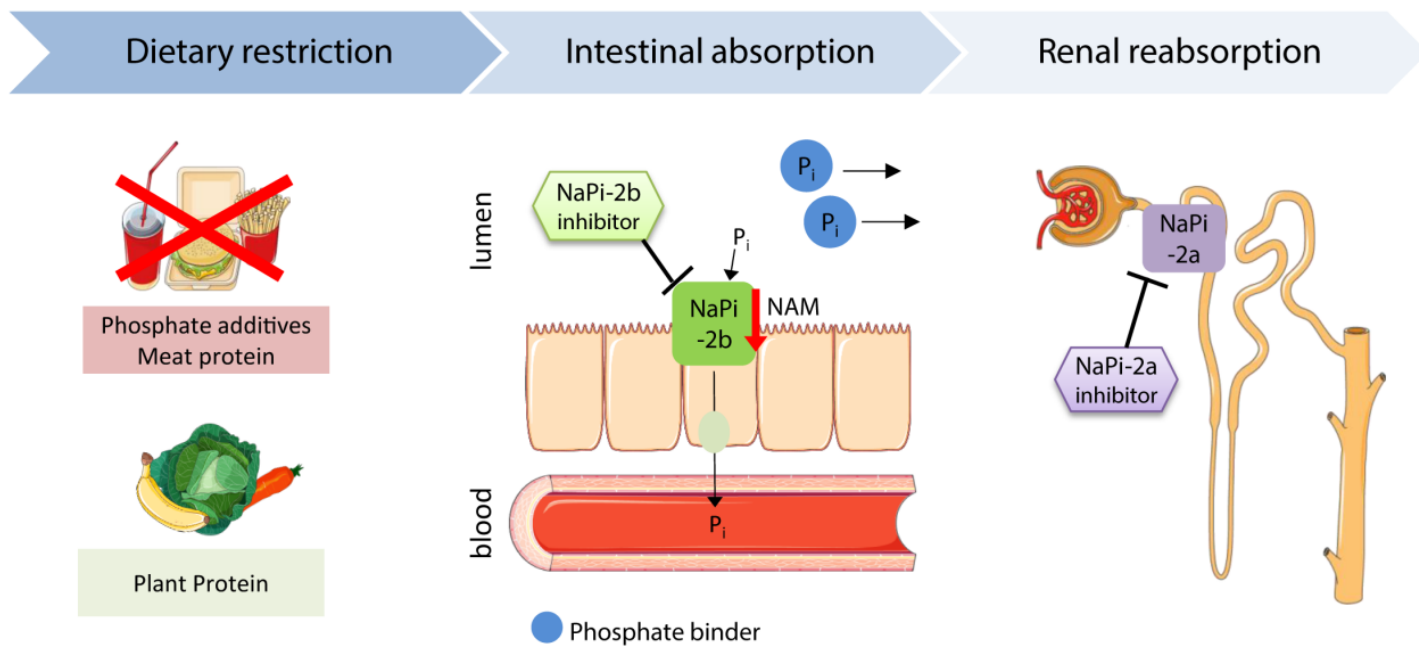

Figure 2. Clinical and experimental therapeutic strategies to target phosphate homeostasis in CKD. Dietary phosphate restriction and inhibition of the intestinal phosphate absorption by phosphate binders and NAM are common phosphate-lowering treatments in CKD patients. Experimental studies investigate the direct targeting of the intestinal phosphate absorption and renal reabsorption by $\mathrm{NaPi}-2 \mathrm{~b}$ or $\mathrm{NaPi}-2 \mathrm{a}$ inhibitors. NaPi-2a/b, type IIa/b sodium-dependent phosphate transporter; NAM, nicotinamide.

The uptake of phosphate depends not only on the amount of phosphate, but also on the source. The bioavailability increases from organic plant phosphate to organic animal phosphate and, finally, additives of the food industry [142]. In uremic rats, feeding of a plant-based diet significantly reduced 
FGF23 levels compared with a meat-based diet, but serum phosphate levels were not altered [143]. Likewise, clinical studies in CKD patients showed a FGF23 lowering effect of vegetarian diets [144,145]. Moe et al. indicated that the vegetarian diet reduces serum phosphate levels as well. This study included a small cohort of nine participants, who received a vegetarian and meat diet with equivalent nutrients under controlled conditions [144]. In contrast, Scialla et al. did not find a correlation between the percentage of plant protein intake and serum phosphate levels in a large cohort of 2938 CKD patients. Instead of a strict control of the diet, data were collected in patient interviews [145]. Thus, the results probably differ because of the divergent study setup. Clinical studies in ESKD patients showed that restricted consumption of inorganic phosphate additives attenuates serum phosphate levels. Unfortunately, serum FGF23 was not investigated in these studies [146,147]. Moreover, a low protein diet reduces serum FGF23 and phosphate levels in non-dialysis and dialysis CKD patients [148,149]. However, reduction of total protein intake was associated with an increased mortality [148]. A general restriction of protein uptake is not a suitable therapeutic strategy to reduce serum phosphate and FGF23 levels, instead, the bioavailability of phosphate in nourishment has to be considered. Less consumption of processed food with phosphate additives and meat might have beneficial clinical outcomes. Future studies need to investigate if restricted phosphate uptake improves the general and cardiovascular outcome in CKD patients.

\subsection{Phosphate Binder}

Phosphate binders sequester phosphate, and thus prevent its gastrointestinal absorption (Figure 2). The non-calcium based phosphate binders sevelamer carbonate and ferric citrate lower FGF23 levels in CKD patients, whereas lanthanum carbonate does not show a consistent effect in controlling FGF23 levels [150-155]. In contrast, calcium-containing phosphate binders did not lower or even increased serum FGF23 levels and promoted the progression of vascular calcification (Table 1) $[150,151,156]$. Hence, calcium-containing phosphate binders are rather inappropriate to treat CKD patients. Clinical trials analyzing the actual cardiac outcome of a phosphate binder therapy in CKD patients are still lacking.

Recent studies indicate beneficial effects of ferric citrate treatment for CKD patients [157-159]. Block et al. showed in a placebo-controlled clinical trial in non-dialysis CKD patients that ferric citrate significantly reduces intact FGF23 and serum phosphate levels among patients with elevated baseline phosphate $(\geq 4.5 \mathrm{mg} / \mathrm{dL})$. The treatment did not affect phosphate levels in patients with lower baseline serum phosphate levels [157]. Besides controlling phosphate and FGF23 levels, ferric citrate may have beneficial effects on CKD-related anemia by increasing hemoglobin, ferritin, and transferrin saturation [158]. As shown by Francis et al., ferric citrate not only reduces FGF23 and phosphate levels, but also improves the renal and cardiac function in the Col4a3 knockout mouse model of progressive CKD. Treatment with ferric citrate reduced blood urea nitrogen levels and albuminuria, two important markers of kidney function. Col4a3 knockout mice receiving ferric citrate also showed less renal interstitial fibrosis and tubular atrophy than Col4a3 knockout control mice. Furthermore, the Col4a3 knockout mice developed severe cardiac dysfunctions, which could be attenuated by ferric citrate treatment. Without treatment, the Col4a3 knockout had an average ejection fraction of $48 \%$, which was improved to $65 \%$ in treated animals. This might be attributed to the reduced FGF23 levels, because ferric citrate treatment decreased circulating FGF23 and the cardiac expression of FGFR4, calcineurin/NFAT, and subsequent hypertrophic target genes in the heart. Overall, ferric citrate slowed the progression of CKD and improved the survival of CKD mice. Interestingly, the protective effects of ferric citrate were higher when the Col4a3 knockout mice were treated in the early stages of CKD compared with a later onset of therapy [159]. If clinical trials can confirm findings of this animal study, ferric citrate and other non-calcium-phosphate binder represent promising drugs to improve cardiac and kidney function in CKD patients. 
Table 1. Advantages and disadvantages of clinically tested phosphate- and fibroblast growth factor receptor 23 (FGF23)-lowering therapies.

\begin{tabular}{|c|c|c|c|}
\hline Class of drug & Drug & Advantages & Disadvantages \\
\hline \multirow{4}{*}{$\begin{array}{l}\text { Non-calcium } \\
\text { phosphate binders }\end{array}$} & Sevelamer & $\begin{array}{l}\text { Lower intact FGF23 and } \\
\text { urinary Pi secretion, } \\
\text { hypolipidemic [150-152] }\end{array}$ & $\begin{array}{l}\text { GI side effects, high pill burden, unchanged } \\
\text { serum Pi [150-152] }\end{array}$ \\
\hline & & & Unchanged serum Pi and intact \\
\hline & Lanthanum carbonate & $\begin{array}{l}\text { Good GI tolerance, lower } \\
\text { C-term FGF23 [154] }\end{array}$ & $\begin{array}{c}\text { FGF23 }[151,155,160] \text {, low solubility: } \\
\text { tissue accumulation might cause } \\
\text { long-term toxicity }\end{array}$ \\
\hline & Ferric citrate & $\begin{array}{l}\text { Lower serum Pi and intact } \\
\text { FGF23, increase hemoglobin } \\
\text { and ferritin }[153,157,158]\end{array}$ & Mild GI side effects $[153,157,158]$ \\
\hline $\begin{array}{l}\text { Calcium-based } \\
\text { phosphate binders }\end{array}$ & $\begin{array}{c}\text { Calcium } \\
\text { carbonate/acetate }\end{array}$ & $\begin{array}{l}\text { Controlled }[150,151] \text { or } \\
\text { lower [161] serum Pi }\end{array}$ & $\begin{array}{c}\text { Hypercalcemia, VC, unchanged or } \\
\text { increased intact FGF23 }[150,151]\end{array}$ \\
\hline Nicotinamide & & $\begin{array}{l}\text { Lower serum Pi and intact } \\
\text { FGF23 in dialysis } \\
\text { patients [162-164] }\end{array}$ & $\begin{array}{l}\text { Unchanged serum Pi and intact FGF23 in } \\
\text { non-dialysis patients [160], mild GI side } \\
\text { effects, at high doses } \\
\text { hepatotoxic/thrombocytopenia [162-166] }\end{array}$ \\
\hline \multirow[t]{2}{*}{$\begin{array}{l}\text { Magnesium } \\
\text { supplements }\end{array}$} & Oral magnesium oxide & Slower progression of VC [167] & $\begin{array}{l}\text { Unchanged serum Pi, FGF23 not measured, } \\
\text { Mild GI side effects [167] }\end{array}$ \\
\hline & $\begin{array}{l}\text { Higher dialysate } \\
\text { magnesium }\end{array}$ & $\begin{array}{l}\text { Increased conversion time } \\
\text { from primary CPP to } \\
\text { secondary CPP (T50 test, } \\
\text { lower serum Pi [168] }\end{array}$ & $\begin{array}{l}\text { Unchanged serum Pi, FGF23 not } \\
\text { measured [168] }\end{array}$ \\
\hline $\begin{array}{l}\text { Pi-transporter } \\
\text { inhibitor }\end{array}$ & $\mathrm{NaPi}-2 \mathrm{~b}$ inhibitor & & Not effective in reducing serum $\mathrm{Pi}$ [169] \\
\hline
\end{tabular}

\subsection{Nicotinamide}

Nicotinamide (niacin, vitamin B3) reduces the dietary phosphate absorption by suppressing the expression of the intestinal phosphate transporter $\mathrm{NaPi}-2 \mathrm{~b}$ (Figure 2) $[170,171]$. Several clinical studies showed that 8-12 weeks of nicotinamide treatment efficiently lowers serum phosphate levels by $12 \%$ to $34 \%$ in ESKD patients on dialysis [162-166]. Besides the phosphate reduction, Rao et al. demonstrated a FGF23-lowering effect of nicotinamide in a randomized, placebo-controlled trial. Nicotinamide treatment for 24 weeks decreased serum FGF23 levels by $11 \%$ among patients with CKD stages 2/3b (eGFR 30-74 mL/min/1.73 $\mathrm{m}^{2}$ ) (Table 1) [172]. More recently, Ix et al. evaluated whether nicotinamide or the phosphate binder lanthanum carbonate alone or in combination are suitable to reduce serum FGF23 and phosphate levels in stage 3b/4 CKD patients during a long-term follow-up of 12 months. The randomized, placebo-controlled study included 205 non-dialysis patients with a mean eGFR of $32 \mathrm{~mL} / \mathrm{min} / 1.73 \mathrm{~m}^{2}$. Neither nicotinamide or lanthanum carbonate alone, nor a combination, significantly lowered serum phosphate or FGF23 over a period of 12 months [160]. Future studies have to consider new approaches for the long-term control of FGF23 and phosphate levels in non-dialysis CKD patients. In CKD patients on dialysis, nicotinamide might have beneficial clinical outcomes owing to the reduction of serum FGF23 and phosphate levels.

\subsection{Magnesium}

In vitro studies showed that magnesium attenuates phosphate-induced calcification in VSMCs (Figure 3) $[173,174]$. Recently, ter Braake et al. demonstrated that secondary CPP-mediated calcification in VSMCs can be reduced by magnesium supplementation. Magnesium delayed dose-dependently the conversion of the harmless primary CPPs into the toxic secondary CPP [175]. Therefore, magnesium supplements might be a promising tool to reduce hyperphosphatemia-associated cardiovascular risk in CKD patients. The cardiovascular mortality risk decreased with increasing magnesium levels in hemodialysis patients with elevated serum phosphate levels $\geq 6 \mathrm{mg} / \mathrm{dL}$ [176]. High serum phosphate and low serum magnesium levels further correlated with an accelerated CKD progression during a median follow-up of 44 months in CKD patients [177]. 


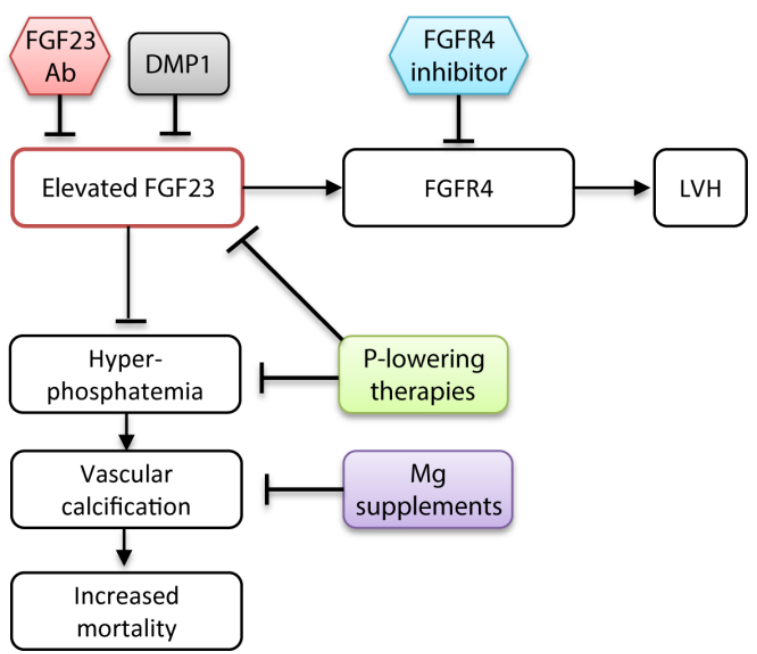

Figure 3. Potential treatments to target FGF23 levels and cardiovascular disease in CKD. Administration of the FGF23 Ab or DMP1 reduces FGF23 levels, but also leads to more severe VC and increased mortality. Thus, application of FGF23-reducing therapies is only conceivable together with a phosphate-lowering therapy or magnesium supplements that decrease phosphate-induced VC. The FGFR4 inhibitor specifically blocks the FGF23-mediated development of LVH. FGF23 Ab, fibroblast growth factor 23 antibody; DMP1, dentin matrix protein 1; FGFR4, fibroblast growth factor receptor 4; Mg, magnesium; $\mathrm{LVH}$, left ventricular hypertrophy.

Sakaguchi et al. examined underlying mechanisms in heminephrectomized mice that received a high phosphate/normal magnesium or high phosphate/low magnesium diet. The low magnesium diet aggravated phosphate-induced tubular injuries and interstitial fibrosis in the kidney. Moreover, low magnesium upregulated the expression of the phosphate transporter $\mathrm{NaPi}-2 \mathrm{a}$ in the kidney, and thereby suppressed urinary phosphate excretion [178]. Contrary to the low magnesium diet, high magnesium levels may mitigate phosphate-induced kidney injuries in CKD patients. Furthermore, magnesium citrate treatment reduced serum phosphate levels and aortic calcification in rats with adenine- and phosphate-induced renal failure. The decreased VC was associated with a downregulation of the pro-chondrogenic marker Runx2 and upregulation of $\mathrm{SM} \alpha$ actin [179]. Recently, Kaesler et al. investigated the effects of magnesium carbonate or nicotinamide alone or in combination, especially on VC in 5/6 nephrectomized mice. All treatments significantly lowered serum FGF23 levels, whereas serum phosphate was only slightly reduced compared with the untreated CKD mice. Magnesium carbonate and the combined treatment reduced VC in the heart, aorta, and kidneys, while nicotinamide alone even enhanced VC. Treatment with magnesium carbonate stimulated the protein expression of the intestinal $\mathrm{NaPi}-2 \mathrm{~b}$ and type III sodium-dependent phosphate transporter Pit-1, which could not be observed in nicotinamide or combined treated CKD mice. In the kidney, nicotinamide and magnesium carbonate alone induced $\mathrm{NaPi}-2 \mathrm{~b}$ expression; this was abolished by the combined treatment [180]. Against the therapeutic goal, increased expression of the phosphate transporters could enhance the phosphate absorption in the intestine and reabsorption in the kidney. Thus, a combined treatment probably is most suitable to reduce VC and phosphate intake in CKD patients.

A preliminary clinical trial including 125 participants showed that oral magnesium oxide slowed the progression of coronary artery calcification in stage 3/4 CKD patients during a follow-up of two years (Table 1). Thereby, the dropout rate was $10 \%$ higher in the magnesium oxide treated group compared with the control group, mainly because of diarrhea. Treatment with magnesium oxide did not influence serum phosphate levels and FGF23 levels were not measured in this study [167]. Additionally, Bressendorff et al. showed that higher dialysate magnesium increased the conversion time of primary CPP into secondary CPP in ESKD patients undergoing dialysis. The conversion time was measured by the $T_{50}$ test, which indicates the risk of $\mathrm{VC}$. Thereby, a prolonged conversion time 
indicates a lower risk of VC, because VC is only mediated by the secondary CPP. High dialysate magnesium also reduced serum phosphate levels [168]. The experimental and clinical studies provide evidence that magnesium supplementation is an appropriate strategy to reduce the progression of VC in CKD patients and might help to control FGF23 and phosphate levels. Hence, future studies should investigate if magnesium supplementation can reduce the cardiovascular mortality in CKD patients.

\subsection{Other Approaches}

Another approach to control serum phosphate levels is to target the phosphate absorption and reabsorption directly using phosphate transporter inhibitors (Figure 2). NaPi-2b-deficient uremic mice exhibit lower serum phosphate and FGF23 levels than wild type uremic mice [181]. However, Larsson et al. showed that two weeks' treatment of ESKD patients with the NaPi-2b inhibitor ASP3325 failed to reduce serum phosphate levels (Table 1) [169]. Recently, Thomas et al. assessed the effects of a NaPi-2a inhibitor in healthy and uremic mice. In both mouse models, the NaPi-2a inhibitor increased the excretion of phosphate in a dose-dependent manner and reduced plasma phosphate and PTH levels [182]. Clinical studies will have to investigate the outcome of NaPi-2a inhibition in CKD patients. According to the previous studies, promoting phosphate excretion might be more efficient than reducing the absorption to control the serum phosphate level. It is also conceivable that a combined treatment, which inhibits both intestinal absorption and renal reabsorption, could have the most beneficial effect for CKD patients.

Experimental studies showed that neutralization or knockout of FGF23 worsens the cardiovascular outcome in uremic mice models owing to phosphate-induced calcification [7,8]. A general FGF23 inhibition without targeting elevated phosphate levels is probably detrimental for CKD patients. Accordingly, therapeutic strategies should specifically prevent the harmful off-target effects of FGF23 without compromising its phosphaturic actions (Figure 3). Administration of a global FGFR blocker attenuated the development of LVH in a CKD mouse model [120,122]. However, this might induce adverse side effects in the kidney. A more specific FGFR4 antibody inhibited FGF23-induced hypertrophy of cardiomyocytes in vitro. Ablation of FGFR4 in mice prevented the development of LVH at high serum FGF23 levels [121]. The direct targeting of FGFR4 is a promising approach to inhibit FGF23-mediated off-target effects in CKD patients.

Recently, Dussold et al. demonstrated the osteocyte protein dentin matrix protein 1 (DMP1) as a feasible therapeutic target to control FGF23 levels and improve cardiac and bone health in CKD patients. The Col4a4 knockout CKD mouse model displayed reduced levels of DMP1 compared with wild type mice. Genetic and pharmacological administration of DMP1 lowered serum FGF23 levels, prevented development of $\mathrm{LVH}$, and corrected bone mass in Col4a4 knockout mice. Despite the positive effects, DMP1 also enhanced hyperphosphatemia [183]. Nevertheless, together with a phosphate lowering therapy, DMP1 might represent a promising target to improve the cardiac function and bone health in CKD patients.

\section{Conclusions}

Elevated FGF23 levels and hyperphosphatemia are risk factors for the excessively increased cardiovascular mortality in CKD patients. FGF23 can act directly on the heart and promote LVH. Apart from that, FGF23 plays a key role in controlling serum phosphate levels to attenuate phosphate-induced VC and hypertension. Treatment of FGF23 levels alone is inappropriate for CKD patients because it reinforces hyperphosphatemia and the associated toxic effects. Hence, former therapeutic strategies focus mainly on phosphate-lowering approaches that in consequence will also reduce FGF23 levels. Many studies demonstrated that dietary phosphate restriction, phosphate binders, or nicotinamide reduce phosphate and FGF23 levels, but studies showing the actual outcome on the cardiovascular system are missing. Recent experimental studies provide evidence for further promising therapeutic strategies, such as direct targeting of phosphate or FGFRs or magnesium supplementation to prevent toxicity of FGF23 and hyperphosphatemia in CKD patients. 
Author Contributions: Conceptualization, I.V. and M.L.-N.; writing—original draft preparation, I.V.; writing—review and editing, I.V., M.L.-N., and D.H.; supervision, M.L.-N. and D.H.

Funding: We acknowledge support by the German Research Foundation (DFG) and the Open Access Publication Fund of Hannover Medical School (MHH).

Conflicts of Interest: The authors declare no conflict of interest.

\section{References}

1. Thompson, S.; James, M.; Wiebe, N.; Hemmelgarn, B.; Manns, B.; Klarenbach, S.; Tonelli, M. Cause of Death in Patients with Reduced Kidney Function. JASN 2015, 26, 2504-2511. [CrossRef] [PubMed]

2. Jimbo, R.; Shimosawa, T. Cardiovascular Risk Factors and Chronic Kidney Disease-FGF23: A Key Molecule in the Cardiovascular Disease. Int. J. Hypertens. 2014, 2014, 381082. [CrossRef] [PubMed]

3. Isakova, T.; Wahl, P.; Vargas, G.S.; Gutiérrez, O.M.; Scialla, J.; Xie, H.; Appleby, D.; Nessel, L.; Bellovich, K.; Chen, J.; et al. Fibroblast Growth Factor 23 is Elevated before Parathyroid Hormone and Phosphate in Chronic Kidney Disease. Kidney Int. 2011, 79, 1370-1378. [CrossRef] [PubMed]

4. Palmer, S.C.; Hayen, A.; Macaskill, P.; Pellegrini, F.; Craig, J.C.; Elder, G.J.; Strippoli, G.F.M. Serum Levels of Phosphorus, Parathyroid Hormone, and Calcium and Risks of Death and Cardiovascular Disease in Individuals with Chronic Kidney Disease: A Systematic Review and Meta-Analysis. JAMA 2011, 305, 1119-1127. [CrossRef] [PubMed]

5. Ritter, C.S.; Slatopolsky, E. Phosphate Toxicity in CKD: The Killer among Us. CJASN 2016, 11, $1088-1100$. [CrossRef] [PubMed]

6. Rodelo-Haad, C.; Santamaria, R.; Muñoz-Castañeda, J.R.; Pendón-Ruiz de Mier, M.V.; Martin-Malo, A.; Rodriguez, M. FGF23, Biomarker Or Target? Toxins 2019, 11, 175. [CrossRef]

7. Shalhoub, V.; Shatzen, E.M.; Ward, S.C.; Davis, J.; Stevens, J.; Bi, V.; Renshaw, L.; Hawkins, N.; Wang, W.; Chen, C.; et al. FGF23 Neutralization Improves Chronic Kidney Disease-associated Hyperparathyroidism Yet Increases Mortality. J. Clin. Investig. 2012, 122, 2543-2553. [CrossRef]

8. Clinkenbeard, E.L.; Noonan, M.L.; Thomas, J.C.; Ni, P.; Hum, J.M.; Aref, M.; Swallow, E.A.; Moe, S.M.; Allen, M.R.; White, K.E. Increased FGF23 Protects Against Detrimental Cardio-Renal Consequences during Elevated Blood Phosphate in CKD. Jci Insight 2019, 4, 123817. [CrossRef]

9. Ben-Dov, I.Z.; Galitzer, H.; Lavi-Moshayoff, V.; Goetz, R.; Kuro-o, M.; Mohammadi, M.; Sirkis, R.; Naveh-Many, T.; Silver, J. The Parathyroid is a Target Organ for FGF23 in Rats. J. Clin. Investig. 2007, 117, 4003-4008. [CrossRef]

10. Saji, F.; Shigematsu, T.; Sakaguchi, T.; Ohya, M.; Orita, H.; Maeda, Y.; Ooura, M.; Mima, T.; Negi, S. Fibroblast Growth Factor 23 Production in Bone is Directly Regulated by 1 $\alpha$, 25-Dihydroxyvitamin D., but Not PTH. Am. J. Physiol.-Ren. Physiol. 2010, 299, F1212-F1217. [CrossRef]

11. Perwad, F.; Azam, N.; Zhang, M.Y.; Yamashita, T.; Tenenhouse, H.S.; Portale, A.A. Dietary and Serum Phosphorus Regulate Fibroblast Growth Factor 23 Expression and 1,25-Dihydroxyvitamin D Metabolism in Mice. Endocrinology 2005, 146, 5358-5364. [CrossRef] [PubMed]

12. Nguyen-Yamamoto, L.; Karaplis, A.C.; St-Arnaud, R.; Goltzman, D. Fibroblast Growth Factor 23 Regulation by Systemic and Local Osteoblast-Synthesized 1,25-Dihydroxyvitamin D. J. Am. Soc. Nephrol. 2017, 28, 586-597. [CrossRef] [PubMed]

13. Chande, S.; Bergwitz, C. Role of Phosphate Sensing in Bone and Mineral Metabolism. Nat. Rev. Endocrinol. 2018, 1, 637-655. [CrossRef] [PubMed]

14. Tagliabracci, V.S.; Engel, J.L.; Wiley, S.E.; Xiao, J.; Gonzalez, D.J.; Appaiah, H.N.; Koller, A.; Nizet, V.; White, K.E.; Dixon, J.E. Dynamic Regulation of FGF23 by Fam20C Phosphorylation, GalNAc-T3 Glycosylation, and Furin Proteolysis. Proc. Natl. Acad. Sci. USA 2014, 111, 5520-5525. [CrossRef] [PubMed]

15. Urakawa, I.; Yamazaki, Y.; Shimada, T.; Iijima, K.; Hasegawa, H.; Okawa, K.; Fujita, T.; Fukumoto, S.; Yamashita, T. Klotho Converts Canonical FGF Receptor into a Specific Receptor for FGF23. Nature 2006, 444, 770. [CrossRef]

16. Shimada, T.; Hasegawa, H.; Yamazaki, Y.; Muto, T.; Hino, R.; Takeuchi, Y.; Fujita, T.; Nakahara, K.; Fukumoto, S.; Yamashita, T. FGF-23 is a Potent Regulator of Vitamin D Metabolism and Phosphate Homeostasis. J. Bone Miner. Res. 2004, 19, 429-435. [CrossRef] 
17. Marks, J.; Srai, S.K.; Biber, J.; Murer, H.; Unwin, R.J.; Debnam, E.S. Intestinal Phosphate Absorption and the Effect of Vitamin D: A Comparison of Rats with Mice. Exp. Physiol. 2006, 91, 531-537. [CrossRef]

18. Komaba, H.; Fukagawa, M. FGF23-parathyroid Interaction: Implications in Chronic Kidney Disease. Kidney Int. 2010, 77, 292-298. [CrossRef]

19. Pereira, R.C.; Jûppner, H.; Azucena-Serrano, C.E.; Yadin, O.; Salusky, I.B.; Wesseling-Perry, K. Patterns of FGF-23, DMP1, and MEPE Expression in Patients with Chronic Kidney Disease. Bone 2009, 45, 1161-1168. [CrossRef]

20. Santamaría, R.; Díaz-Tocados, J.M.; de Mier, M.V.P.R.; Robles, A.; Salmerón-Rodríguez, M.D.; Ruiz, E.; Vergara, N.; Aguilera-Tejero, E.; Raya, A.; Ortega, R.; et al. Increased Phosphaturia Accelerates the Decline in Renal Function: A Search for Mechanisms. Sci. Rep. 2018, 8, 13701. [CrossRef]

21. Antoniucci, D.M.; Yamashita, T.; Portale, A.A. Dietary Phosphorus Regulates Serum Fibroblast Growth Factor-23 Concentrations in Healthy Men. J. Clin. Endocrinol. Metab. 2006, 91, 3144-3149. [CrossRef] [PubMed]

22. Tsai, W.; Wu, H.; Peng, Y.; Hsu, S.; Chiu, Y.; Chen, H.; Yang, J.; Ko, M.; Pai, M.; Tu, Y. Effects of Lower Versus Higher Phosphate Diets on Fibroblast Growth Factor-23 Levels in Patients with Chronic Kidney Disease: A Systematic Review and Meta-Analysis. Nephrol. Dial. Transplant. 2018, 33, 1977-1983. [CrossRef] [PubMed]

23. Gutierrez, O.; Isakova, T.; Rhee, E.; Shah, A.; Holmes, J.; Collerone, G.; Jüppner, H.; Wolf, M. Fibroblast Growth Factor-23 Mitigates Hyperphosphatemia but Accentuates Calcitriol Deficiency in Chronic Kidney Disease. J. Am. Soc. Nephrol. 2005, 16, 2205-2215. [CrossRef] [PubMed]

24. Hasegawa, H.; Nagano, N.; Urakawa, I.; Yamazaki, Y.; Iijima, K.; Fujita, T.; Yamashita, T.; Fukumoto, S.; Shimada, T. Direct Evidence for a Causative Role of FGF23 in the Abnormal Renal Phosphate Handling and Vitamin D Metabolism in Rats with Early-Stage Chronic Kidney Disease. Kidney Int. 2010, 78, 975-980. [CrossRef]

25. Komaba, H.; Fukagawa, M. The Role of FGF23 in CKD-With or without Klotho. Nat. Rev. Nephrol. 2012, 8, 484. [CrossRef]

26. Hu, M.C.; Kuro-o, M.; Moe, O.W. Klotho and chronic kidney disease. Contrib. Nephrol. 2013, 180, 47-63. [CrossRef]

27. Kuro-o, M. No Title. Klotho in chronic kidney disease-What's new? Nephrol. Dial. Transplant. 2009, 24, 1705-1708. [CrossRef]

28. Koh, N.; Fujimori, T.; Nishiguchi, S.; Tamori, A.; Shiomi, S.; Nakatani, T.; Sugimura, K.; Kishimoto, T.; Kinoshita, S.; Kuroki, T. Severely Reduced Production of Klotho in Human Chronic Renal Failure Kidney. Biochem. Biophys. Res. Commun. 2001, 280, 1015-1020. [CrossRef]

29. Jean, G.; Terrat, J.; Vanel, T.; Hurot, J.; Lorriaux, C.; Mayor, B.; Chazot, C. High Levels of Serum Fibroblast Growth Factor (FGF)-23 are Associated with Increased Mortality in Long Haemodialysis Patients. Nephrol. Dial. Transplant. 2009, 24, 2792-2796. [CrossRef]

30. Gutiérrez, O.M.; Mannstadt, M.; Isakova, T.; Rauh-Hain, J.A.; Tamez, H.; Shah, A.; Smith, K.; Lee, H.; Thadhani, R.; Jüppner, H. Fibroblast Growth Factor 23 and Mortality among Patients Undergoing Hemodialysis. N. Engl. J. Med. 2008, 359, 584-592. [CrossRef]

31. Isakova, T.; Xie, H.; Yang, W.; Xie, D.; Anderson, A.H.; Scialla, J.; Wahl, P.; Gutiérrez, O.M.; Steigerwalt, S.; He, J. Fibroblast Growth Factor 23 and Risks of Mortality and End-Stage Renal Disease in Patients with Chronic Kidney Disease. JAMA 2011, 305, 2432-2439. [CrossRef] [PubMed]

32. Lavi-Moshayoff, V.; Wasserman, G.; Meir, T.; Silver, J.; Naveh-Many, T. PTH Increases FGF23 Gene Expression and Mediates the High-FGF23 Levels of Experimental Kidney Failure: A Bone Parathyroid Feedback Loop. Am. J. Physiol.-Ren. Physiol. 2010, 299, F882-F889. [CrossRef] [PubMed]

33. López, I.; Rodríguez-Ortiz, M.E.; Almadén, Y.; Guerrero, F.; De Oca, A.M.; Pineda, C.; Shalhoub, V.; Rodríguez, M.; Aguilera-Tejero, E. Direct and Indirect Effects of Parathyroid Hormone on Circulating Levels of Fibroblast Growth Factor 23 in Vivo. Kidney Int. 2011, 80, 475-482. [CrossRef] [PubMed]

34. Nishi, H.; Nii-Kono, T.; Nakanishi, S.; Yamazaki, Y.; Yamashita, T.; Fukumoto, S.; Ikeda, K.; Fujimori, A.; Fukagawa, M. Intravenous Calcitriol Therapy Increases Serum Concentrations of Fibroblast Growth Factor-23 in Dialysis Patients with Secondary Hyperparathyroidism. Nephron Clin. Pract. 2005, 101, c94-c99. [CrossRef] [PubMed] 
35. Charoenngam, N.; Rujirachun, P.; Holick, M.F.; Ungprasert, P. Oral Vitamin D 3 Supplementation Increases Serum Fibroblast Growth Factor 23 Concentration in Vitamin D-Deficient Patients: A Systematic Review and Meta-Analysis. Osteoporos. Int. 2019, 30, 2183-2193. [CrossRef] [PubMed]

36. Komaba, H.; Goto, S.; Fujii, H.; Hamada, Y.; Kobayashi, A.; Shibuya, K.; Tominaga, Y.; Otsuki, N.; Nibu, K.; Nakagawa, K. Depressed Expression of Klotho and FGF Receptor 1 in Hyperplastic Parathyroid Glands from Uremic Patients. Kidney Int. 2010, 77, 232-238. [CrossRef]

37. Canalejo, R.; Canalejo, A.; Martinez-Moreno, J.M.; Rodriguez-Ortiz, M.E.; Estepa, J.C.; Mendoza, F.J.; Munoz-Castaneda, J.R.; Shalhoub, V.; Almaden, Y.; Rodriguez, M. FGF23 Fails to Inhibit Uremic Parathyroid Glands. J. Am. Soc. Nephrol. 2010, 21, 1125-1135. [CrossRef]

38. Galitzer, H.; Ben-Dov, I.Z.; Silver, J.; Naveh-Many, T. Parathyroid Cell Resistance to Fibroblast Growth Factor 23 in Secondary Hyperparathyroidism of Chronic Kidney Disease. Kidney Int. 2010, 77, 211-218. [CrossRef]

39. Kendrick, J.; Cheung, A.K.; Kaufman, J.S.; Greene, T.; Roberts, W.L.; Smits, G.; Chonchol, M.; HOST Investigators. FGF-23 Associates with Death, Cardiovascular Events, and Initiation of Chronic Dialysis. J. Am. Soc. Nephrol. 2011, 22, 1913-1922. [CrossRef]

40. Kestenbaum, B.; Sampson, J.N.; Rudser, K.D.; Patterson, D.J.; Seliger, S.L.; Young, B.; Sherrard, D.J.; Andress, D.L. Serum Phosphate Levels and Mortality Risk among People with Chronic Kidney Disease. J. Am. Soc. Nephrol. 2005, 16, 520-528. [CrossRef]

41. Menon, V.; Greene, T.; Pereira, A.A.; Wang, X.; Beck, G.J.; Kusek, J.W.; Collins, A.J.; Levey, A.S.; Sarnak, M.J. Relationship of Phosphorus and Calcium-Phosphorus Product with Mortality in CKD. Am. J. Kidney Dis. 2005, 46, 455-463. [CrossRef] [PubMed]

42. Voormolen, N.; Noordzij, M.; Grootendorst, D.C.; Beetz, I.; Sijpkens, Y.W.; Van Manen, J.G.; Boeschoten, E.W.; Huisman, R.M.; Krediet, R.T.; Dekker, F.W. High Plasma Phosphate as a Risk Factor for Decline in Renal Function and Mortality in Pre-Dialysis Patients. Nephrol. Dial. Transplant. 2007, 22, 2909-2916. [CrossRef] [PubMed]

43. Eddington, H.; Hoefield, R.; Sinha, S.; Chrysochou, C.; Lane, B.; Foley, R.N.; Hegarty, J.; New, J.; O'Donoghue, D.J.; Middleton, R.J. Serum Phosphate and Mortality in Patients with Chronic Kidney Disease. Clin. J. Am. Soc. Nephrol. 2010, 5, 2251-2257. [CrossRef]

44. Rao, M.V.; Qiu, Y.; Wang, C.; Bakris, G. Hypertension and CKD: Kidney Early Evaluation Program (KEEP) and National Health and Nutrition Examination Survey (NHANES), 1999-2004. Am. J. Kidney Dis. 2008, 51, S30-S37. [CrossRef] [PubMed]

45. Fyfe-Johnson, A.; Alonso, A.; Selvin, E.; Bower, J.; Pankow, J.; Agarwal, S.; Lutsey, P. Serum Fibroblast Growth Factor-23 and Incident Hypertension: The Atherosclerosis Risk in Communities Study. J. Hypertens. 2016, 34, 1266-1272. [CrossRef] [PubMed]

46. Akhabue, E.; Montag, S.; Reis, J.; Pool, L.; Mehta, R.; Yancy, C.; Zhao, L.; Wolf, M.; Gutierrez, O.; Carnethon, M.; et al. FGF23 (Fibroblast Growth Factor-23) and Incident Hypertension in Young and Middle-Aged Adults: The CARDIA Study. Hypertension 2018, 72, 70-76. [CrossRef] [PubMed]

47. Lin, Y.; Shi, L.; Liu, Y.; Zhang, H.; Liu, Y.; Huang, X.; Hou, D.; Zhang, M. Plasma Fibroblast Growth Factor 23 is Elevated in Pediatric Primary Hypertension. Front. Pediatrics 2019, 7, 135. [CrossRef]

48. Mendes, M.; Resende, L.; Teixeira, A.; Correia, J.; Silva, G. Blood Pressure and Phosphate Level in Diabetic and Non-Diabetic Kidney Disease: Results of the Cross-Sectional "Low Clearance Consultation" Study. Porto Biomed. J. 2017, 2, 301-305. [CrossRef]

49. Mohammad, J.; Scanni, R.; Bestmann, L.; Hulter, H.N.; Krapf, R. A Controlled Increase in Dietary Phosphate Elevates BP in Healthy Human Subjects. J. Am. Soc. Nephrol. Jasn 2018, 29, 2089-2098. [CrossRef]

50. Li, Y.C.; Kong, J.; Wei, M.; Chen, Z.F.; Liu, S.Q.; Cao, L.P. 1,25-Dihydroxyvitamin D(3) is a Negative Endocrine Regulator of the Renin-Angiotensin System. J. Clin. Investig. 2002, 110, 229. [CrossRef]

51. de Borst, M.H.; Vervloet, M.G.; ter Wee, P.M.; Navis, G. Cross Talk between the Renin-Angiotensin-Aldosterone System and Vitamin D-FGF-23-Klotho in Chronic Kidney Disease. J. Am. Soc. Nephrol. 2011, 22, 1603-1609. [CrossRef] [PubMed]

52. Crackower, M.A.; Sarao, R.; Oudit, G.Y.; Yagil, C.; Kozieradzki, I.; Scanga, S.E.; Oliveira-dos-Santos, A.J.; da Costa, J.; Zhang, L.; Pei, Y. Angiotensin-Converting Enzyme 2 is an Essential Regulator of Heart Function. Nature 2002, 417, 822. [CrossRef] [PubMed] 
53. Dai, B.; David, V.; Martin, A.; Huang, J.; Li, H.; Jiao, Y.; Gu, W.; Quarles, L.D. A Comparative Transcriptome Analysis Identifying FGF23 Regulated Genes in the Kidney of a Mouse CKD Model. PLoS ONE 2012, 7, e44161. [CrossRef] [PubMed]

54. Andrukhova, O.; Slavic, S.; Smorodchenko, A.; Zeitz, U.; Shalhoub, V.; Lanske, B.; Pohl, E.E.; Erben, R.G. FGF23 Regulates Renal Sodium Handling and Blood Pressure. Embo Mol. Med. 2014, 6, 744-759. [CrossRef]

55. Patel, R.K.; Jeemon, P.; Stevens, K.K.; Mccallum, L.; Hastie, C.E.; Schneider, A.; Jardine, A.G.; Mark, P.B.; Padmanabhan, S. Association between Serum Phosphate and Calcium, Long-Term Blood Pressure, and Mortality in Treated Hypertensive Adults. J. Hypertens. 2015, 33, 2046-2053. [CrossRef]

56. Bozic, M.; Panizo, S.; Sevilla, M.; Riera, M.; Soler, M.; Pascual, J.; Lopez, I.; Freixenet, M.; Fernandez, E.; Valdivielso, J. High Phosphate Diet Increases Arterial Blood Pressure Via a Parathyroid Hormone Mediated Increase of Renin. J. Hypertens. 2014, 32, 1822-1832. [CrossRef]

57. Suzuki, Y.; Mitsushima, S.; Kato, A.; Yamaguchi, T.; Ichihara, S. High-Phosphorus/Zinc-Free Diet Aggravates Hypertension and Cardiac Dysfunction in a Rat Model of the Metabolic Syndrome. Cardiovasc. Pathol. 2014, 23, 43-49. [CrossRef]

58. Mizuno, M.; Mitchell, J.H.; Crawford, S.; Huang, C.; Maalouf, N.; Hu, M.; Moe, O.W.; Smith, S.A.; Vongpatanasin, W. High Dietary Phosphate Intake Induces Hypertension and Augments Exercise Pressor Reflex Function in Rats. American journal of physiology. Regul. Integr. Comp. Physiol. 2016, 311, R39-R48. [CrossRef]

59. Delaney, E.P.; Greaney, J.L.; Edwards, D.G.; Rose, W.C.; Fadel, P.J.; Farquhar, W.B. Exaggerated Sympathetic and Pressor Responses to Handgrip Exercise in Older Hypertensive Humans: Role of the Muscle Metaboreflex. Am. J. Physiol.-Heart Circ. Physiol. 2010, 299, H1318-H1327. [CrossRef]

60. Vongpatanasin, W.; Wang, Z.; Arbique, D.; Arbique, G.; Adams-Huet, B.; Mitchell, J.H.; Victor, R.G.; Thomas, G.D. Functional Sympatholysis is Impaired in Hypertensive Humans. J. Physiol. (Lond.) 2011, 589, 1209-1220. [CrossRef]

61. Goodman, W.G.; Goldin, J.; Kuizon, B.D.; Yoon, C.; Gales, B.; Sider, D.; Wang, Y.; Chung, J.; Emerick, A.; Greaser, L. Coronary-Artery Calcification in Young Adults with End-Stage Renal Disease Who are Undergoing Dialysis. N. Engl. J. Med. 2000, 342, 1478-1483. [CrossRef] [PubMed]

62. Blacher, J.; Guerin, A.P.; Pannier, B.; Marchais, S.J.; London, G.M. Arterial Calcifications, Arterial Stiffness, and Cardiovascular Risk in End-Stage Renal Disease. Hypertension 2001, 38, 938-942. [CrossRef] [PubMed]

63. Russo, D.; Corrao, S.; Battaglia, Y.; Andreucci, M.; Caiazza, A.; Carlomagno, A.; Lamberti, M.; Pezone, N.; Pota, A.; Russo, L. Progression of Coronary Artery Calcification and Cardiac Events in Patients with Chronic Renal Disease Not Receiving Dialysis. Kidney Int. 2011, 80, 112-118. [CrossRef] [PubMed]

64. Nasrallah, M.M.; El-Shehaby, A.R.; Salem, M.M.; Osman, N.A.; El Sheikh, E.; Sharaf El Din, U.A. Fibroblast Growth Factor-23 (FGF-23) is Independently Correlated to Aortic Calcification in Haemodialysis Patients. Nephrol. Dial. Transplant. 2010, 25, 2679-2685. [CrossRef]

65. Desjardins, L.; Liabeuf, S.; Renard, C.; Lenglet, A.; Lemke, H.D.; Choukroun, G.; Drueke, T.B.; Massy, Z.A.; European Uremic Toxin (EUTox) Work Group. FGF23 is Independently Associated with Vascular Calcification but Not Bone Mineral Density in Patients at various CKD Stages. Osteoporos Int. 2012, 23, 2017-2025.

66. Scialla, J.J.; Lau, W.L.; Reilly, M.P.; Isakova, T.; Yang, H.; Crouthamel, M.H.; Chavkin, N.W.; Rahman, M.; Wahl, P.; Amaral, A.P. Fibroblast Growth Factor 23 is Not Associated with and does Not Induce Arterial Calcification. Kidney Int. 2013, 83, 1159-1168. [CrossRef]

67. Lindberg, K.; Olauson, H.; Amin, R.; Ponnusamy, A.; Goetz, R.; Taylor, R.F.; Mohammadi, M.; Canfield, A.; Kublickiene, K.; Larsson, T.E. Arterial Klotho Expression and FGF23 Effects on Vascular Calcification and Function. PLoS ONE 2013, 8, e60658. [CrossRef]

68. Lim, K.; Lu, T.; Molostvov, G.; Lee, C.; Lam, F.T.; Zehnder, D.; Hsiao, L. Vascular Klotho Deficiency Potentiates the Development of Human Artery Calcification and Mediates Resistance to Fibroblast Growth Factor 23. Circulation 2012, 125, 2243-2255. [CrossRef]

69. Zhu, D.; Mackenzie, N.C.; Millan, J.L.; Farquharson, C.; MacRae, V.E. A Protective Role for FGF-23 in Local Defence against Disrupted Arterial Wall Integrity? Mol. Cell. Endocrinol. 2013, 372, 1-11. [CrossRef]

70. Jimbo, R.; Kawakami-Mori, F.; Mu, S.; Hirohama, D.; Majtan, B.; Shimizu, Y.; Yatomi, Y.; Fukumoto, S.; Fujita, T.; Shimosawa, T. Fibroblast Growth Factor 23 Accelerates Phosphate-Induced Vascular Calcification in the Absence of Klotho Deficiency. Kidney Int. 2014, 85, 1103-1111. [CrossRef] 
71. Chen, Y.; Huang, C.; Duan, Z.; Xu, C.; Chen, Y. Klotho/FGF23 Axis Mediates High Phosphate-induced Vascular Calcification in Vascular Smooth Muscle Cells Via Wnt7b/B-catenin Pathway. Kaohsiung J. Med. Sci. 2019, 35, 393-400. [CrossRef] [PubMed]

72. Shigematsu, T.; Kono, T.; Satoh, K.; Yokoyama, K.; Yoshida, T.; Hosoya, T.; Shirai, K. Phosphate Overload Accelerates Vascular Calcium Deposition in End-stage Renal Disease Patients. Nephrol. Dial. Transplant. 2003, 18, iii86-iii89. [CrossRef] [PubMed]

73. Adeney, K.L.; Siscovick, D.S.; Ix, J.H.; Seliger, S.L.; Shlipak, M.G.; Jenny, N.S.; Kestenbaum, B.R. Association of Serum Phosphate with Vascular and Valvular Calcification in Moderate CKD. J. Am. Soc. Nephrol. 2009, 20, 381-387. [CrossRef] [PubMed]

74. El-Abbadi, M.M.; Pai, A.S.; Leaf, E.M.; Yang, H.; Bartley, B.A.; Quan, K.K.; Ingalls, C.M.; Liao, H.W.; Giachelli, C.M. Phosphate Feeding Induces Arterial Medial Calcification in Uremic Mice: Role of Serum Phosphorus, Fibroblast Growth Factor-23, and Osteopontin. Kidney Int. 2009, 75, 1297-1307. [CrossRef] [PubMed]

75. Lau, W.L.; Linnes, M.; Chu, E.Y.; Foster, B.L.; Bartley, B.A.; Somerman, M.J.; Giachelli, C.M. High Phosphate Feeding Promotes Mineral and Bone Abnormalities in Mice with Chronic Kidney Disease. Nephrol. Dial. Transplant. 2012, 28, 62-69. [CrossRef] [PubMed]

76. Shroff, R.C.; McNair, R.; Skepper, J.N.; Figg, N.; Schurgers, L.J.; Deanfield, J.; Rees, L.; Shanahan, C.M. Chronic Mineral Dysregulation Promotes Vascular Smooth Muscle Cell Adaptation and Extracellular Matrix Calcification. J. Am. Soc. Nephrol. 2010, 21, 103-112. [CrossRef]

77. Collins, J.F.; Bai, L.; Ghishan, F.K. The SLC20 Family of Proteins: Dual Functions as Sodium-Phosphate Cotransporters and Viral Receptors. Pflügers Arch. 2004, 447, 647-652. [CrossRef]

78. Li, X.; Yang, H.; Giachelli, C.M. Role of the Sodium-Dependent Phosphate Cotransporter, Pit-1, in Vascular Smooth Muscle Cell Calcification. Circ. Res. 2006, 98, 905-912. [CrossRef]

79. Chavkin, N.W.; Chia, J.J.; Crouthamel, M.H.; Giachelli, C.M. Phosphate Uptake-Independent Signaling Functions of the Type III Sodium-Dependent Phosphate Transporter, PiT-1, in Vascular Smooth Muscle Cells. Exp. Cell Res. 2015, 333, 39-48. [CrossRef]

80. Yamada, S.; Leaf, E.M.; Chia, J.J.; Cox, T.C.; Speer, M.Y.; Giachelli, C.M. PiT-2, a Type III Sodium-Dependent Phosphate Transporter, Protects Against Vascular Calcification in Mice with Chronic Kidney Disease Fed a High-Phosphate Diet. Kidney Int. 2018, 94, 716-727. [CrossRef]

81. Reynolds, J.L.; Joannides, A.J.; Skepper, J.N.; McNair, R.; Schurgers, L.J.; Proudfoot, D.; Jahnen-Dechent, W.; Weissberg, P.L.; Shanahan, C.M. Human Vascular Smooth Muscle Cells Undergo Vesicle-Mediated Calcification in Response to Changes in Extracellular Calcium and Phosphate Concentrations: A Potential Mechanism for Accelerated Vascular Calcification in ESRD. J. Am. Soc. Nephrol. 2004, 15, 2857-2867. [CrossRef] [PubMed]

82. Speer, M.Y.; Li, X.; Hiremath, P.G.; Giachelli, C.M. Runx2/Cbfa1, but Not Loss of Myocardin, is Required for Smooth Muscle Cell Lineage Reprogramming Toward Osteochondrogenesis. J. Cell. Biochem. 2010, 110, 935-947. [CrossRef] [PubMed]

83. Chen, N.X.; O'Neill, K.D.; Duan, D.; Moe, S.M. Phosphorus and Uremic Serum Up-Regulate Osteopontin Expression in Vascular Smooth Muscle Cells. Kidney Int. 2002, 62, 1724-1731. [CrossRef] [PubMed]

84. Li, X.; Yang, H.; Giachelli, C.M. BMP-2 Promotes Phosphate Uptake, Phenotypic Modulation, and Calcification of Human Vascular Smooth Muscle Cells. Atherosclerosis 2008, 199, 271-277. [CrossRef]

85. Steitz, S.A.; Speer, M.Y.; Curinga, G.; Yang, H.; Haynes, P.; Aebersold, R.; Schinke, T.; Karsenty, G.; Giachelli, C.M. Smooth Muscle Cell Phenotypic Transition Associated with Calcification: Upregulation of Cbfa1 and Downregulation of Smooth Muscle Lineage Markers. Circ. Res. 2001, 89, 1147-1154. [CrossRef]

86. Shanahan, C.M.; Crouthamel, M.H.; Kapustin, A.; Giachelli, C.M. Arterial Calcification in Chronic Kidney Disease: Key Roles for Calcium and Phosphate. Circ. Res. 2011, 109, 697-711. [CrossRef]

87. Boström, K.I.; Rajamannan, N.M.; Towler, D.A. The Regulation of Valvular and Vascular Sclerosis by Osteogenic Morphogens. Circ. Res. 2011, 109, 564-577. [CrossRef]

88. Cheng, L.; Zhang, L.; Yang, J.; Hao, L. Activation of Peroxisome Proliferator-Activated Receptor $\Gamma$ Inhibits Vascular Calcification by Upregulating Klotho. Exp. Ther. Med. 2017, 13, 467-474. [CrossRef]

89. Liu, C.; Liu, Y.; Liu, L.; Zhang, J.; Zhang, Y.; Zhang, B.; Zhang, Z.; Bi, X.; Nie, L.; Xiong, J.; et al. High Phosphate-Induced Downregulation of PPAR $\gamma$ Contributes to CKD-Associated Vascular Calcification. J. Mol. Cell. Cardiol. 2018, 114, 264-275. [CrossRef] 
90. Mihai, S.; Codrici, E.; Popescu, I.D.; Enciu, A.; Albulescu, L.; Necula, L.G.; Mambet, C.; Anton, G.; Tanase, C. Inflammation-Related Mechanisms in Chronic Kidney Disease Prediction, Progression, and Outcome. J. Immunol. Res. 2018, 2018, 2180373. [CrossRef]

91. Hénaut, L.; Massy, Z.A. New Insights into the Key Role of Interleukin 6 in Vascular Calcification of Chronic Kidney Disease. Nephrol. Dial. Transplant. 2018, 33, 543-548. [CrossRef]

92. Mendoza, J.M.; Isakova, T.; Ricardo, A.C.; Xie, H.; Navaneethan, S.D.; Anderson, A.H.; Bazzano, L.A.; Xie, D.; Kretzler, M.; Nessel, L. Fibroblast Growth Factor 23 and Inflammation in CKD. Clin. J. Am. Soc. Nephrol. 2012, 7, 1155-1162. [CrossRef] [PubMed]

93. Hanks, L.J.; Casazza, K.; Judd, S.E.; Jenny, N.S.; Gutiérrez, O.M. Associations of Fibroblast Growth Factor-23 with Markers of Inflammation, Insulin Resistance and Obesity in Adults. PLoS ONE 2015, 10, e0122885. [CrossRef]

94. Wallquist, C.; Mansouri, L.; Norrbäck, M.; Hylander, B.; Jacobson, S.H.; Larsson, T.E.; Lundahl, J. Associations of Fibroblast Growth Factor 23 with Markers of Inflammation and Leukocyte Transmigration in Chronic Kidney Disease. Nephron 2018, 138, 287-295. [CrossRef]

95. David, V.; Martin, A.; Isakova, T.; Spaulding, C.; Qi, L.; Ramirez, V.; Zumbrennen-Bullough, K.B.; Sun, C.C.; Lin, H.Y.; Babitt, J.L. Inflammation and Functional Iron Deficiency Regulate Fibroblast Growth Factor 23 Production. Kidney Int. 2016, 89, 135-146. [CrossRef] [PubMed]

96. Durlacher-Betzer, K.; Hassan, A.; Levi, R.; Axelrod, J.; Silver, J.; Naveh-Many, T. Interleukin-6 Contributes to the Increase in Fibroblast Growth Factor 23 Expression in Acute and Chronic Kidney Disease. Kidney Int. 2018, 94, 315-325. [CrossRef] [PubMed]

97. Egli-Spichtig, D.; Silva, P.H.I.; Glaudemans, B.; Gehring, N.; Bettoni, C.; Zhang, M.; Arroyo, E.P.; Schönenberger, D.; Rajski, M.; Hoogewijis, D. Tumor Necrosis Factor Stimulates Fibroblast Growth Factor 23 Levels in Chronic Kidney Disease and Non-Renal Inflammation. Kidney Int. 2019, 96, 890-905. [CrossRef] [PubMed]

98. Han, X.; Li, L.; Yang, J.; King, G.; Xiao, Z.; Quarles, L.D. Counter-regulatory Paracrine Actions of FGF-23 and 1,25 (OH) 2D in Macrophages. Febs Lett. 2016, 590, 53-67. [CrossRef]

99. Singh, S.; Grabner, A.; Yanucil, C.; Schramm, K.; Czaya, B.; Krick, S.; Czaja, M.J.; Bartz, R.; Abraham, R.; Di Marco, G.S. Fibroblast Growth Factor 23 Directly Targets Hepatocytes to Promote Inflammation in Chronic Kidney Disease. Kidney Int. 2016, 90, 985-996. [CrossRef]

100. Aghagolzadeh, P.; Bachtler, M.; Bijarnia, R.; Jackson, C.; Smith, E.R.; Odermatt, A.; Radpour, R.; Pasch, A. Calcification of Vascular Smooth Muscle Cells is Induced by Secondary Calciprotein Particles and Enhanced by Tumor Necrosis Factor-A. Atherosclerosis 2016, 251, 404-414. [CrossRef]

101. Pazár, B.; Ea, H.; Narayan, S.; Kolly, L.; Bagnoud, N.; Chobaz, V.; Roger, T.; Lioté, F.; So, A.; Busso, N. Basic Calcium Phosphate Crystals Induce Monocyte/Macrophage IL-1 $\beta$ Secretion through the NLRP3 Inflammasome in Vitro. J. Immunol. 2011, 186, 2495-2502. [CrossRef] [PubMed]

102. Tintut, Y.; Patel, J.; Parhami, F.; Demer, L.L. Tumor Necrosis Factor-A Promotes in Vitro Calcification of Vascular Cells Via the cAMP Pathway. Circulation 2000, 102, 2636-2642. [CrossRef] [PubMed]

103. Awan, Z.; Denis, M.; Roubtsova, A.; Essalmani, R.; Marcinkiewicz, J.; Awan, A.; Gram, H.; Seidah, N.G.; Genest, J. Reducing Vascular Calcification by Anti-IL-1 $\beta$ Monoclonal Antibody in a Mouse Model of Familial Hypercholesterolemia. Angiology 2016, 67, 157-167. [CrossRef] [PubMed]

104. Ceneri, N.; Zhao, L.; Young, B.D.; Healy, A.; Coskun, S.; Vasavada, H.; Yarovinsky, T.O.; Ike, K.; Pardi, R.; Qin, L. Rac2 Modulates Atherosclerotic Calcification by Regulating Macrophage Interleukin-1 $\beta$ Production. Arterioscler. Thromb. Vasc. Biol. 2017, 37, 328-340. [CrossRef] [PubMed]

105. Bhatnagar, S.; Panguluri, S.K.; Gupta, S.K.; Dahiya, S.; Lundy, R.F.; Kumar, A. Tumor Necrosis Factor-A Regulates Distinct Molecular Pathways and Gene Networks in Cultured Skeletal Muscle Cells. PLoS ONE 2010, 5, e13262. [CrossRef]

106. Azpiazu, D.; Gonzalo, S.; Villa-Bellosta, R. Tissue Non-Specific Alkaline Phosphatase and Vascular Calcification: A Potential Therapeutic Target. Curr. Cardiol. Rev. 2019, 15, 91-95. [CrossRef]

107. Zickler, D.; Luecht, C.; Willy, K.; Chen, L.; Witowski, J.; Girndt, M.; Fiedler, R.; Storr, M.; Kamhieh-Milz, J.; Schoon, J. Tumour Necrosis Factor-Alpha in Uraemic Serum Promotes Osteoblastic Transition and Calcification of Vascular Smooth Muscle Cells Via Extracellular Signal-Regulated Kinases and Activator Protein 1/C-FOS-Mediated Induction of Interleukin 6 Expression. Nephrol. Dial. Transplant. 2017, 33, 574-585. [CrossRef] 
108. Agharazii, M.; St-Louis, R.; Gautier-Bastien, A.; Ung, R.; Mokas, S.; Larivière, R.; Richard, D.E. Inflammatory Cytokines and Reactive Oxygen Species as Mediators of Chronic Kidney Disease-Related Vascular Calcification. Am. J. Hypertens. 2014, 28, 746-755. [CrossRef]

109. Reynolds, J.L.; Skepper, J.N.; McNair, R.; Kasama, T.; Gupta, K.; Weissberg, P.L.; Jahnen-Dechent, W.; Shanahan, C.M. Multifunctional Roles for Serum Protein Fetuin-a in Inhibition of Human Vascular Smooth Muscle Cell Calcification. J. Am. Soc. Nephrol. 2005, 16, 2920-2930. [CrossRef] [PubMed]

110. Levin, A.; Thompson, C.R.; Ethier, J.; Carlisle, E.J.; Tobe, S.; Mendelssohn, D.; Burgess, E.; Jindal, K.; Barrett, B.; Singer, J. Left Ventricular Mass Index Increase in Early Renal Disease: Impact of Decline in Hemoglobin. Am. J. Kidney Dis. 1999, 34, 125-134. [CrossRef]

111. Foley, R.N.; Parfrey, P.S.; Harnett, J.D.; Kent, G.M.; Martin, C.J.; Murray, D.C.; Barre, P.E. Clinical and Echocardiographic Disease in Patients Starting End-Stage Renal Disease Therapy. Kidney Int. 1995, 47, 186-192. [CrossRef] [PubMed]

112. Paoletti, E.; Bellino, D.; Cassottana, P.; Rolla, D.; Cannella, G. Left Ventricular Hypertrophy in Nondiabetic Predialysis CKD. Am. J. Kidney Dis. 2005, 46, 320-327. [CrossRef] [PubMed]

113. Hsu, H.J.; Wu, M. Fibroblast Growth Factor 23: A Possible Cause of Left Ventricular Hypertrophy in Hemodialysis Patients. Am. J. Med. Sci. 2009, 337, 116-122. [CrossRef] [PubMed]

114. Mirza, M.A.; Larsson, A.; Melhus, H.; Lind, L.; Larsson, T.E. Serum Intact FGF23 Associate with Left Ventricular Mass, Hypertrophy and Geometry in an Elderly Population. Atherosclerosis 2009, 207, 546-551. [CrossRef]

115. Kirkpantur, A.; Balci, M.; Gurbuz, O.A.; Afsar, B.; Canbakan, B.; Akdemir, R.; Ayli, M.D. Serum Fibroblast Growth Factor-23 (FGF-23) Levels are Independently Associated with Left Ventricular Mass and Myocardial Performance Index in Maintenance Haemodialysis Patients. Nephrol. Dial. Transplant. 2011, 26, 1346-1354. [CrossRef]

116. Negishi, K.; Kobayashi, M.; Ochiai, I.; Yamazaki, Y.; Hasegawa, H.; Yamashita, T.; Shimizu, T.; Kasama, S.; Kurabayashi, M. Association between Fibroblast Growth Factor 23 and Left Ventricular Hypertrophy in Maintenance Hemodialysis Patients. Circ. J. 2010, 74, 2734-2740. [CrossRef]

117. Seeherunvong, W.; Abitbol, C.; Chandar, J.; Rusconi, P.; Zilleruelo, G.; Freundlich, M. Fibroblast Growth Factor 23 and Left Ventricular Hypertrophy in Children on Dialysis. Pediatr. Nephrol. 2012, 27, 2129-2136. [CrossRef]

118. Mitsnefes, M.M.; Betoko, A.; Schneider, M.F.; Salusky, I.B.; Wolf, M.S.; Jüppner, H.; Warady, B.A.; Furth, S.L.; Portale, A.A. FGF23 and Left Ventricular Hypertrophy in Children with CKD. Clin. J. Am. Soc. Nephrol. Cjasn 2018, 13, 45-52. [CrossRef]

119. Leifheit-Nestler, M.; große Siemer, R.; Flasbart, K.; Richter, B.; Kirchhoff, F.; Ziegler, W.H.; Klintschar, M.; Becker, J.U.; Erbersdobler, A.; Aufricht, C. Induction of Cardiac FGF23/FGFR4 Expression is Associated with Left Ventricular Hypertrophy in Patients with Chronic Kidney Disease. Nephrol. Dial. Transplant. 2015, 31, 1088-1099. [CrossRef]

120. Faul, C.; Amaral, A.P.; Oskouei, B.; Hu, M.; Sloan, A.; Isakova, T.; Gutiérrez, O.M.; Aguillon-Prada, R.; Lincoln, J.; Hare, J.M.; et al. FGF23 Induces Left Ventricular Hypertrophy. J. Clin. Investig. 2011, 121, 4393-4408. [CrossRef]

121. Grabner, A.; Amaral, A.P.; Schramm, K.; Singh, S.; Sloan, A.; Yanucil, C.; Li, J.; Shehadeh, L.A.; Hare, J.M.; David, V. Activation of Cardiac Fibroblast Growth Factor Receptor 4 Causes Left Ventricular Hypertrophy. Cell Metab. 2015, 22, 1020-1032. [CrossRef]

122. Di Marco, G.S.; Reuter, S.; Kentrup, D.; Grabner, A.; Amaral, A.P.; Fobker, M.; Stypmann, J.; Pavenstädt, H.; Wolf, M.; Faul, C. Treatment of Established Left Ventricular Hypertrophy with Fibroblast Growth Factor Receptor Blockade in an Animal Model of CKD. Nephrol. Dial. Transplant. 2014, 29, 2028-2035. [CrossRef]

123. Molkentin, J.D. Calcineurin-NFAT Signaling Regulates the Cardiac Hypertrophic Response in Coordination with the MAPKs. Cardiovasc. Res. 2004, 63, 467-475. [CrossRef]

124. Takashi, Y.; Kinoshita, Y.; Hori, M.; Ito, N.; Taguchi, M.; Fukumoto, S. Patients with FGF23-Related Hypophosphatemic Rickets/Osteomalacia do Not Present with Left Ventricular Hypertrophy. Endocr. Res. 2017, 42, 132-137. [CrossRef]

125. Leifheit-Nestler, M.; Richter, B.; Basaran, M.; Nespor, J.; Vogt, I.; Alesutan, I.; Voelkl, J.; Lang, F.; Heineke, J.; Krick, S. Impact of Altered Mineral Metabolism on Pathological Cardiac Remodeling in Elevated Fibroblast Growth Factor 23. Front. Endocrinol. 2018, 9, 333. [CrossRef] 
126. Pastor-Arroyo, E.; Gehring, N.; Krudewig, C.; Costantino, S.; Bettoni, C.; Knöpfel, T.; Sabrautzki, S.; Lorenz-Depiereux, B.; Pastor, J.; Strom, T.M. The Elevation of Circulating Fibroblast Growth Factor 23 without Kidney Disease does Not Increase Cardiovascular Disease Risk. Kidney Int. 2018, 94, 49-59. [CrossRef]

127. Faul, C. FGF23 Effects on the Heart-Levels, Time, Source, And context Matter. Kidney Int. 2018, 94, 7-11. [CrossRef]

128. Foley, R.N.; Collins, A.J.; Herzog, C.A.; Ishani, A.; Kalra, P.A. Serum Phosphate and Left Ventricular Hypertrophy in Young Adults: The Coronary Artery Risk Development in Young Adults Study. Kidney Blood Press. Res. 2009, 32, 37-44. [CrossRef]

129. Saab, G.; Whooley, M.A.; Schiller, N.B.; Ix, J.H. Association of Serum Phosphorus with Left Ventricular Mass in Men and Women with Stable Cardiovascular Disease: Data from the Heart and Soul Study. Am. J. Kidney Dis. 2010, 56, 496-505. [CrossRef]

130. Chue, C.D.; Edwards, N.C.; Moody, W.E.; Steeds, R.P.; Townend, J.N.; Ferro, C.J. Serum Phosphate is Associated with Left Ventricular Mass in Patients with Chronic Kidney Disease: A Cardiac Magnetic Resonance Study. Heart 2012, 98, 219-224. [CrossRef]

131. Yamamoto, K.T.; Robinson-Cohen, C.; De Oliveira, M.C.; Kostina, A.; Nettleton, J.A.; Ix, J.H.; Nguyen, H.; Eng, J.; Lima, J.A.; Siscovick, D.S. Dietary Phosphorus is Associated with Greater Left Ventricular Mass. Kidney Int. 2013, 83, 707-714. [CrossRef]

132. Zou, J.; Yu, Y.; Wu, P.; Lin, F.; Yao, Y.; Xie, Y.; Jiang, G. Serum Phosphorus is Related to Left Ventricular Remodeling Independent of Renal Function in Hospitalized Patients with Chronic Kidney Disease. Int. J. Cardiol. 2016, 221, 134-140. [CrossRef]

133. Amann, K.; Törnig, J.; Kugel, B.; Gross, M.; Tyralla, K.; El-Shakmak, A.; Szabo, A.; Ritz, E. Hyperphosphatemia Aggravates Cardiac Fibrosis and Microvascular Disease in Experimental Uremia. Kidney Int. 2003, 63, 1296-1301. [CrossRef]

134. Neves, K.R.; Graciolli, F.G.; Dos Reis, L.M.; Pasqualucci, C.A.; Moyses, R.M.; Jorgetti, V. Adverse Effects of Hyperphosphatemia on Myocardial Hypertrophy, Renal Function, and Bone in Rats with Renal Failure. Kidney Int. 2004, 66, 2237-2244. [CrossRef]

135. Peri-Okonny, P.; Baskin, K.K.; Iwamoto, G.; Mitchell, J.H.; Smith, S.A.; Kim, H.K.; Szweda, L.I.; Bassel-Duby, R.; Fujikawa, T.; Castorena, C.M. High-Phosphate Diet Induces Exercise Intolerance and Impairs Fatty Acid Metabolism in Mice. Circulation 2019, 139, 1422-1434. [CrossRef]

136. Hu, M.C.; Shi, M.; Cho, H.J.; Adams-Huet, B.; Paek, J.; Hill, K.; Shelton, J.; Amaral, A.P.; Faul, C.; Taniguchi, M. Klotho and Phosphate are Modulators of Pathologic Uremic Cardiac Remodeling. J. Am. Soc. Nephrol. 2015, 26, 1290-1302. [CrossRef]

137. Hu, M.C.; Scanni, R.; Ye, J.; Zhang, J.; Shi, M.; Maique, J.; Flores, B.; Moe, O.W.; Krapf, R. Dietary Vitamin D Interacts with High Phosphate-induced Cardiac Remodeling in Rats with Normal Renal Function. Nephrol. Dial. Transplant. 2019, gfz156. [CrossRef]

138. Liu, Y.; Huang, C.; Chang, C.; Chou, C.; Lin, S.; Wang, I.; Hsieh, D.J.; Jong, G.; Huang, C.; Wang, C. Hyperphosphate-Induced Myocardial Hypertrophy through the GATA-4/NFAT-3 Signaling Pathway is Attenuated by ERK Inhibitor Treatment. Cardiorenal Med. 2015, 5, 79-88. [CrossRef]

139. Ferrari, S.L.; Bonjour, J.; Rizzoli, R. Fibroblast Growth Factor-23 Relationship to Dietary Phosphate and Renal Phosphate Handling in Healthy Young Men. J. Clin. Endocrinol. Metab. 2005, 90, 1519-1524. [CrossRef]

140. Burnett, S.M.; Gunawardene, S.C.; Bringhurst, F.R.; Jüppner, H.; Lee, H.; Finkelstein, J.S. Regulation of C-terminal and Intact FGF-23 by Dietary Phosphate in Men and Women. J. Bone Miner. Res. 2006, 21, 1187-1196. [CrossRef]

141. Tsai, W.; Wu, H.; Peng, Y.; Hsu, S.; Chiu, Y.; Yang, J.; Chen, H.; Pai, M.; Lin, W.; Hung, K. Short-Term Effects of very-Low-Phosphate and Low-Phosphate Diets on Fibroblast Growth Factor 23 in Hemodialysis Patients: A Randomized Crossover Trial. Clin. J. Am. Soc. Nephrol. 2019, 14, 1475-1483. [CrossRef] [PubMed]

142. Kalantar-Zadeh, K.; Gutekunst, L.; Mehrotra, R.; Kovesdy, C.P.; Bross, R.; Shinaberger, C.S.; Noori, N.; Hirschberg, R.; Benner, D.; Nissenson, A.R. Understanding Sources of Dietary Phosphorus in the Treatment of Patients with Chronic Kidney Disease. Clin. J. Am. Soc. Nephrol. 2010, 5, 519-530. [CrossRef] [PubMed]

143. Moe, S.M.; Chen, N.X.; Seifert, M.F.; Sinders, R.M.; Duan, D.; Chen, X.; Liang, Y.; Radcliff, J.S.; White, K.E.; Gattone II, V.H. A Rat Model of Chronic Kidney Disease-Mineral Bone Disorder. Kidney Int. 2009, 75, $176-184$. [CrossRef] [PubMed] 
144. Moe, S.M.; Zidehsarai, M.P.; Chambers, M.A.; Jackman, L.A.; Radcliffe, J.S.; Trevino, L.L.; Donahue, S.E.; Asplin, J.R. Vegetarian Compared with Meat Dietary Protein Source and Phosphorus Homeostasis in Chronic Kidney Disease. Clin. J. Am. Soc. Nephrol. 2011, 6, 257-264. [CrossRef] [PubMed]

145. Scialla, J.J.; Appel, L.J.; Wolf, M.; Yang, W.; Zhang, X.; Sozio, S.M.; Miller, E.R., III; Bazzano, L.A.; Cuevas, M.; Glenn, M.J. Plant Protein Intake is Associated with Fibroblast Growth Factor 23 and Serum Bicarbonate Levels in Patients with Chronic Kidney Disease: The Chronic Renal Insufficiency Cohort Study. J. Ren. Nutr. 2012, 22, 37-388. [CrossRef]

146. Sullivan, C.; Sayre, S.S.; Leon, J.B.; Machekano, R.; Love, T.E.; Porter, D.; Marbury, M.; Sehgal, A.R. Effect of Food Additives on Hyperphosphatemia among Patients with End-Stage Renal Disease: A Randomized Controlled Trial. JAMA 2009, 301, 629-635. [CrossRef]

147. de Fornasari, M.L.L.; dos Santos Sens, Y.A. Replacing Phosphorus-Containing Food Additives with Foods without Additives Reduces Phosphatemia in End-Stage Renal Disease Patients: A Randomized Clinical Trial. J. Ren. Nutr. 2017, 27, 97-105. [CrossRef]

148. Shinaberger, C.S.; Greenland, S.; Kopple, J.D.; Van Wyck, D.; Mehrotra, R.; Kovesdy, C.P.; Kalantar-Zadeh, K. Is Controlling Phosphorus by Decreasing Dietary Protein Intake Beneficial Or Harmful in Persons with Chronic Kidney Disease? Am. J. Clin. Nutr. 2008, 88, 1511-1518. [CrossRef]

149. Di Iorio, B.; Di Micco, L.; Torraca, S.; Sirico, M.L.; Russo, L.; Pota, A.; Mirenghi, F.; Russo, D. Acute Effects of very-Low-Protein Diet on FGF23 Levels: A Randomized Study. Clin. J. Am. Soc. Nephrol. 2012, 7, 581-587. [CrossRef]

150. Oliveira, R.B.; Cancela, A.L.; Graciolli, F.G.; Dos Reis, L.M.; Draibe, S.A.; Cuppari, L.; Carvalho, A.B.; Jorgetti, V.; Canziani, M.E.; Moysés, R.M. Early Control of PTH and FGF23 in Normophosphatemic CKD Patients: A New Target in CKD-MBD Therapy? Clin. J. Am. Soc. Nephrol. 2010, 5, 286-291. [CrossRef]

151. Block, G.A.; Wheeler, D.C.; Persky, M.S.; Kestenbaum, B.; Ketteler, M.; Spiegel, D.M.; Allison, M.A.; Asplin, J.; Smits, G.; Hoofnagle, A.N. Effects of Phosphate Binders in Moderate CKD. J. Am. Soc. Nephrol. 2012, 23, 1407-1415. [CrossRef] [PubMed]

152. Patel, L.; Bernard, L.M.; Elder, G.J. Sevelamer Versus Calcium-Based Binders for Treatment of Hyperphosphatemia in CKD: A Meta-Analysis of Randomized Controlled Trials. Clin. J. Am. Soc. Nephrol. 2016, 11, 232-244. [CrossRef] [PubMed]

153. Yokoyama, K.; Hirakata, H.; Akiba, T.; Fukagawa, M.; Nakayama, M.; Sawada, K.; Kumagai, Y.; Block, G.A. Ferric Citrate Hydrate for the Treatment of Hyperphosphatemia in Nondialysis-Dependent CKD. Clin. J. Am. Soc. Nephrol. 2014, 9, 543-552. [CrossRef] [PubMed]

154. Gonzalez-Parra, E.; Gonzalez-Casaus, M.L.; Galán, A.; Martinez-Calero, A.; Navas, V.; Rodriguez, M.; Ortiz, A. Lanthanum Carbonate Reduces FGF23 in Chronic Kidney Disease Stage 3 Patients. Nephrol. Dial. Transplant. 2011, 26, 2567-2571. [CrossRef] [PubMed]

155. Isakova, T.; Barchi-Chung, A.; Enfield, G.; Smith, K.; Vargas, G.; Houston, J.; Xie, H.; Wahl, P.; Schiavenato, E.; Dosch, A. Effects of Dietary Phosphate Restriction and Phosphate Binders on FGF23 Levels in CKD. Clin. J. Am. Soc. Nephrol. 2013, 8, 1009-1018. [CrossRef] [PubMed]

156. Jamal, S.A.; Vandermeer, B.; Raggi, P.; Mendelssohn, D.C.; Chatterley, T.; Dorgan, M.; Lok, C.E.; Fitchett, D.; Tsuyuki, R.T. Effect of Calcium-Based Versus Non-Calcium-Based Phosphate Binders on Mortality in Patients with Chronic Kidney Disease: An Updated Systematic Review and Meta-Analysis. Lancet 2013, 382, 1268-1277. [CrossRef]

157. Block, G.A.; Pergola, P.E.; Fishbane, S.; Martins, J.G.; LeWinter, R.D.; Uhlig, K.; Neylan, J.F.; Chertow, G.M. Effect of Ferric Citrate on Serum Phosphate and Fibroblast Growth Factor 23 among Patients with Nondialysis-Dependent Chronic Kidney Disease: Path Analyses. Nephrol. Dial. Transplant. 2018, 34, 1115-1124. [CrossRef]

158. Block, G.A.; Block, M.S.; Smits, G.; Mehta, R.; Isakova, T.; Wolf, M.; Chertow, G.M. A Pilot Randomized Trial of Ferric Citrate Coordination Complex for the Treatment of Advanced CKD. J. Am. Soc. Nephrol. 2019, 30, 1495-1504. [CrossRef]

159. Francis, C.; Courbon, G.; Gerber, C.; Neuburg, S.; Wang, X.; Dussold, C.; Capella, M.; Qi, L.; Isakova, T.; Mehta, R. Ferric Citrate Reduces Fibroblast Growth Factor 23 Levels and Improves Renal and Cardiac Function in a Mouse Model of Chronic Kidney Disease. Kidney Int. 2019, in press. [CrossRef] 
160. Ix, J.H.; Isakova, T.; Larive, B.; Raphael, K.L.; Raj, D.S.; Cheung, A.K.; Sprague, S.M.; Fried, L.F.; Gassman, J.J.; Middleton, J.P. Effects of Nicotinamide and Lanthanum Carbonate on Serum Phosphate and Fibroblast Growth Factor-23 in CKD: The COMBINE Trial. J. Am. Soc. Nephrol. 2019, 30, 1096-1108. [CrossRef]

161. Qunibi, W.; Winkelmayer, W.C.; Solomon, R.; Moustafa, M.; Kessler, P.; Ho, C.; Greenberg, J.; Diaz-Buxo, J.A. A Randomized, Double-Blind, Placebo-Controlled Trial of Calcium Acetate on Serum Phosphorus Concentrations in Patients with Advanced Non-Dialysis-Dependent Chronic Kidney Disease. BMC Nephrol. 2011, 12, 9. [CrossRef] [PubMed]

162. Young, D.O.; Cheng, S.C.; Delmez, J.A.; Coyne, D.W. The Effect of Oral Niacinamide on Plasma Phosphorus Levels in Peritoneal Dialysis Patients. Perit. Dial. Int. 2009, 29, 562-567. [PubMed]

163. Shahbazian, H.; Shahbazian, H.; Zafar Mohtashami, A.; Zafar Mohtashami, A.; Ghorbani, A.; Ghorbani, A.; Abbaspour, M.R.; Abbaspour, M.R.; Belladi Musavi, S.S.; Musavi, B. Oral Nicotinamide Reduces Serum Phosphorus, Increases HDL, and Induces Thrombocytopenia in Hemodialysis Patients: A Double-Blind Randomized Clinical Trial. Nefrología (Engl. Ed.) 2011, 31, 58-65.

164. Vasantha, J.; Soundararajan, P.; Vanitharani, N.; Kannan, G.; Thennarasu, P.; Neenu, G.; Reddy, C.U. Safety and Efficacy of Nicotinamide in the Management of Hyperphosphatemia in Patients on Hemodialysis. Indian J. Nephrol. 2011, 21, 245. [CrossRef]

165. Takahashi, Y.; Tanaka, A.; Nakamura, T.; Fukuwatari, T.; Shibata, K.; Shimada, N.; Ebihara, I.; Koide, H. Nicotinamide Suppresses Hyperphosphatemia in Hemodialysis Patients. Kidney Int. 2004, 65, 1099-1104. [CrossRef]

166. Cheng, S.C.; Young, D.O.; Huang, Y.; Delmez, J.A.; Coyne, D.W. A Randomized, Double-Blind, Placebo-Controlled Trial of Niacinamide for Reduction of Phosphorus in Hemodialysis Patients. Clin. J. Am. Soc. Nephrol. 2008, 3, 1131-1138. [CrossRef]

167. Sakaguchi, Y.; Hamano, T.; Obi, Y.; Monden, C.; Oka, T.; Yamaguchi, S.; Matsui, I.; Hashimoto, N.; Matsumoto, A.; Shimada, K. A Randomized Trial of Magnesium Oxide and Oral Carbon Adsorbent for Coronary Artery Calcification in Predialysis CKD. J. Am. Soc. Nephrol. 2019, 30, 1073-1085. [CrossRef]

168. Bressendorff, I.; Hansen, D.; Schou, M.; Pasch, A.; Brandi, L. The Effect of Increasing Dialysate Magnesium on Serum Calcification Propensity in Subjects with End Stage Kidney Disease A Randomized, Controlled Clinical Trial. Clin. J. Am. Soc. Nephrol. 2018, 13, 1373-1380. [CrossRef]

169. Larsson, T.E.; Kameoka, C.; Nakajo, I.; Taniuchi, Y.; Yoshida, S.; Akizawa, T.; Smulders, R.A. NPT-IIb Inhibition does Not Improve Hyperphosphatemia in CKD. Kidney Int. Rep. 2018, 3, 73-80. [CrossRef]

170. Katai, K.; Tanaka, H.; Tatsumi, S.; Fukunaga, Y.; Genjida, K.; Morita, K.; Kuboyama, N.; Suzuki, T.; Akiba, T.; Miyamoto, K. Nicotinamide Inhibits Sodium-Dependent Phosphate Cotransport Activity in Rat Small Intestine. Nephrol. Dial. Transplant. 1999, 14, 1195-1201. [CrossRef]

171. Eto, N.; Miyata, Y.; Ohno, H.; Yamashita, T. Nicotinamide Prevents the Development of Hyperphosphataemia by Suppressing Intestinal Sodium-Dependent Phosphate Transporter in Rats with Adenine-Induced Renal Failure. Nephrol. Dial. Transplant. 2005, 20, 1378-1384. [CrossRef] [PubMed]

172. Rao, M.; Steffes, M.; Bostom, A.; Ix, J.H. Effect of Niacin on FGF23 Concentration in Chronic Kidney Disease. Am. J. Nephrol. 2014, 39, 484-490. [CrossRef] [PubMed]

173. Louvet, L.; Büchel, J.; Steppan, S.; Passlick-Deetjen, J.; Massy, Z.A. Magnesium Prevents Phosphate-Induced Calcification in Human Aortic Vascular Smooth Muscle Cells. Nephrol. Dial. Transplant. 2012, 28, 869-878. [CrossRef]

174. De Oca, A.M.; Guerrero, F.; Martinez-Moreno, J.M.; Madueno, J.A.; Herencia, C.; Peralta, A.; Almaden, Y.; Lopez, I.; Aguilera-Tejero, E.; Gundlach, K. Magnesium Inhibits Wnt/B-Catenin Activity and Reverses the Osteogenic Transformation of Vascular Smooth Muscle Cells. PLoS ONE 2014, 9, e89525.

175. ter Braake, A.D.; Tinnemans, P.T.; Shanahan, C.M.; Hoenderop, J.G.; de Baaij, J.H. Magnesium Prevents Vascular Calcification in Vitro by Inhibition of Hydroxyapatite Crystal Formation. Sci. Rep. 2018, 8, 2069. [CrossRef]

176. Sakaguchi, Y.; Fujii, N.; Shoji, T.; Hayashi, T.; Rakugi, H.; Iseki, K.; Tsubakihara, Y.; Isaka, Y.; Committee of Renal Data Registry of the Japanese Society for Dialysis Therapy. Magnesium Modifies the Cardiovascular Mortality Risk Associated with Hyperphosphatemia in Patients Undergoing Hemodialysis: A Cohort Study. PLoS ONE 2014, 9, e116273. [CrossRef] 
177. Sakaguchi, Y.; Iwatani, H.; Hamano, T.; Tomida, K.; Kawabata, H.; Kusunoki, Y.; Shimomura, A.; Matsui, I.; Hayashi, T.; Tsubakihara, Y.; et al. Magnesium Modifies the Association between Serum Phosphate and the Risk of Progression to End-Stage Kidney Disease in Patients with Non-Diabetic Chronic Kidney Disease. Kidney Int. 2015, 88, 833-842. [CrossRef]

178. Sakaguchi, Y.; Hamano, T.; Matsui, I.; Oka, T.; Yamaguchi, S.; Kubota, K.; Shimada, K.; Matsumoto, A.; Hashimoto, N.; Isaka, Y. Low Magnesium Diet Aggravates Phosphate-Induced Kidney Injury. Nephrol. Dial. Transplant. 2018, 34, 1310-1319. [CrossRef]

179. Yao, Z.; Xu, Y.; Ma, W.; Sun, X.; Jia, S.; Zheng, Y.; Liu, X.; Fan, Y.; Wang, C. Magnesium Citrate Protects Against Vascular Calcification in an Adenine-Induced Chronic Renal Failure Rat Model. J. Cardiovasc. Pharm. 2018, 72, 270-276. [CrossRef]

180. Kaesler, N.; Goettsch, C.; Weis, D.; Schurgers, L.; Hellmann, B.; Floege, J.; Kramann, R. Magnesium but Not Nicotinamide Prevents Vascular Calcification in Experimental Uraemia. Nephrol. Dial. Transplant. 2019, 1-9. [CrossRef]

181. Schiavi, S.C.; Tang, W.; Bracken, C.; O’Brien, S.P.; Song, W.; Boulanger, J.; Ryan, S.; Phillips, L.; Liu, S.; Arbeeny, C. Npt2b Deletion Attenuates Hyperphosphatemia Associated with CKD. J. Am. Soc. Nephrol. 2012, 23, 1691-1700. [CrossRef] [PubMed]

182. Thomas, L.; Xue, J.; Murali, S.K.; Fenton, R.A.; Rieg, J.A.D.; Rieg, T. Pharmacological Npt2a Inhibition Causes Phosphaturia and Reduces Plasma Phosphate in Mice with Normal and Reduced Kidney Function. J. Am. Soc. Nephrol. 2019, 30, 2128-2139. [CrossRef] [PubMed]

183. Dussold, C.; Gerber, C.; White, S.; Wang, X.; Qi, L.; Francis, C.; Capella, M.; Courbon, G.; Wang, J.; Li, C. DMP1 Prevents Osteocyte Alterations, FGF23 Elevation and Left Ventricular Hypertrophy in Mice with Chronic Kidney Disease. Bone Res. 2019, 7, 12. [CrossRef] [PubMed]

(C) 2019 by the authors. Licensee MDPI, Basel, Switzerland. This article is an open access article distributed under the terms and conditions of the Creative Commons Attribution (CC BY) license (http://creativecommons.org/licenses/by/4.0/). 